\title{
Investigating the deepest part of a volcano plumbing system: Evidence for an active magma path below the western flank of Piton de la Fournaise (La Réunion Island)
}

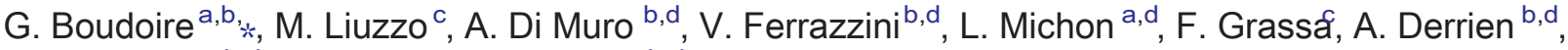

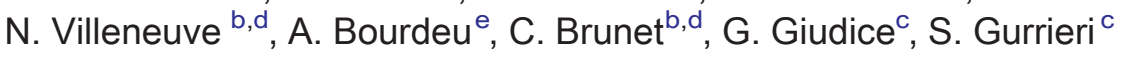

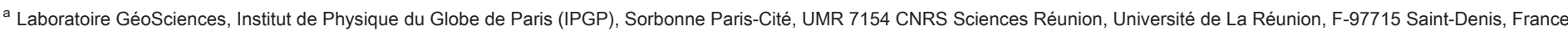

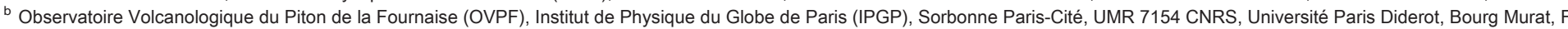 \\ ${ }^{\mathrm{c}}$ Istituto Nazionale di Geofisica e Vulcanologia, Sezione di Palermo, V. Ugo La Malfa 153, - 90146 Palermo, Italy \\ d Institut de Physique du Globe de Paris (IPGP), Sorbonne Paris-Cité, UMR 7154 CNRS, Université Paris Diderot, F-75005 Paris, France \\ e Ecole et Observatoire des Sciences de la Terre (EOST), 5 rue René Descartes, F-67084 Strasbourg, France
}

\section{arti cle info}

\section{Article history:}

Received 25 October 2016

Received in revised form 21 May 2017

Accepted 21 May 2017

Available online 26 May 2017

\section{Keywords:}

Soil $\mathrm{CO}_{2}$ emissions

$\delta^{13} \mathrm{C}$ - isotope tracers

magma migration

photogrammetry

seismicity

\begin{abstract}
Peripheral diffuse degassing of CQfrom the soil occurs across the western flank of Piton de la Fournaise volcano (La Réunion Island, Indian Ocean) along a narrow zone. In this area, carbon isotopic analysis on soil gas samples highlights significant mixing between magmatic and organic end-members. The zones with the strongest magmatic signature (highest $\delta^{13} \mathrm{C}$ ) overlap spatial distribution of hypocenters recorded shortly before and during volcano reactivation and allow discriminating a $\mathrm{N} 135^{\circ}$ degassing lineament, with a minimum length of $11 \mathrm{~km}$ and $140 \pm 20 \mathrm{~m}$-width. Such orientation is in accordance with that of an old dyke network along the rift zone and with $\mathrm{N} 120-130^{\circ}$ and $\mathrm{N} 140-155^{\circ}$ lineaments related to the inheritance of oceanic lithosphere structures. Our findings show that this $\mathrm{N} 135^{\circ}$ lineament represents a preferential magmatic pathway for deep magma transfer below the volcano flank. Moreover, spatial distributions of recent eccentric cones indicate a well-founded possibility that future eruptions may by-pass the shallow plumbing system of the central area of the volcano, taking a lateral pathway along this structure. Our results also confirm that Piton de la Fournaise activity is linked to a laterally shifted plumbing system and represent a major improvement in identifying the main high-risk area on the densely populated western flank of the volcano.
\end{abstract}

\section{Introduction}

At quiescent and active volcanoes, a significant fraction of magma degassing diffuses through edifice flanks and, preferentially, along active tectonic structures (Allard et al., 1991; Giammanco et al., 1995, 1998, 2010; Chiodini et al., 2001; Granieri et al., 2003, 2010; Hernández et al., 2012). Among released volcanic gases, carbon dioxide (CQ) is early by an uprising magma, already at mantle depth and represents the most important contribution to diffuse degassing, whereas water $\left(\mathrm{H}_{2} \mathrm{O}\right)$, the most abundant magmatic volatile species, is released at shallower depths, and undergoes condensation both along its pathways toward the surface, and in the soil (Granieri et al., 2010; Di Muro et al., 2016). Besides magmatic degassing, soil CQdegassing at the surface may also be related to several other sources such as (1) mantle, (2) subducted crustal rocks and sediments, (3) carbonate rocks and, (4) biogenic components

* Corresponding author at: Observatoire Volcanologique du Piton de la Fournaise (OVPF/IPGP), Impasse de l'Observatoire, Bourg Murat 97418, France.

E-mail address: guillaume.boudoire@gmail.com (G. Boudoire).
(Giammanco et al., 1997; Deegan et al., 2010; Troll et al., 2012; Burton et al., 2013; Dionis et al., 2015). Carbon isotopic composition is a useful tool to discriminate between these different sources of $\mathrm{CO}_{2}$ emissions and to reveal potential mixing among gases deriving from different sources. For instance, thanks to carbon isotopes analysis, it is possible to identify interactions between magmatic and hydrothermal fluids in volcanic environments (Giammanco et al., 1998; Chiodini et al., 2008), or to detect any contribution from biogenic gas or from air to the diffusely emitted $\mathrm{CO}_{2}$ (Amundson et al., 1998).

When a deep magmatic origin is inferred, $\mathrm{CO}_{2}$ release from the soil along active tectonic structures generally displays close spatial and temporal links with seismicity. The link between magmatic CO ${ }_{2}$ emission and seismicity in volcanic areas can be related to either (1) permeability variations due to tectonic stress changes and/or rock failure phenomenon connected to the regional geodynamic activity or, (2) magma transfer or intrusion processes. Examples of the first type have been observed along the Pernicana fault at Mount Etna (Italy) (Giammanco et al., 2006; Azzaro et al., 1998; Toutain and Baubron, 1999), as well as along the San Andreas fault near Los Angeles (USA) (Irwin and Barnes, 1980). 
Regarding the second type, many cases have been described by several authors at numerous volcanoes, such as, Mount Etna and Vulcano Island in Italy (Giammanco et al., 1998; Chiodini et al., 1998; Diliberto et al., 2002; Gurrieri et al., 2008; Giammanco and Bonfanti, 2009; Cannata et al., 2010, 2015), or El Hierro in the Canary Islands (López et al., 2012; Pérez et al., 2012).

At Piton de la Fournaise (La Réunion Island), diffuse flank $\mathrm{CO}_{2}$ degassing is generally very weak (Seidel et al., 1988; Marty et al., 1993; Toutain et al., 2002; Liuzzo et al., 2015) and includes a significant biogenic component. This peculiar condition is explicable, most probably, by the tropical oceanic climate, which is marked by extreme precipitation rates and a high average temperature, allowing substratum degradation and fast vegetation development. Some authors (Basile-Doelsch et al., 2007; de Junet et al., 2013) have evidenced that andosols at La Réunion Island have a strong potential organic matter sequestration due to the absence of aluminosilicate minerals. However, recent studies carried out on the whole edifice (Liuzzo et al., 2015) have revealed that at Piton de la Fournaise there are also several sites marked by high soil $\mathrm{CO}_{2}$ fluxes with a $\delta^{13} \mathrm{C}$ signature typical of a magmatic origin of the emitted gas. These authors have performed large-scale campaigns of the volcano flanks with a moderate spatial resolution. They showed that there is a close spatial correlation among sites with anomalous soil $\mathrm{CO} \quad{ }_{2}$ flux, areas exhibiting the highest concentration of eruptive cones on the volcano flanks and the areas with hypocentral location of earthquakes at depths $\mathrm{N} 11 \mathrm{~km}$ (depth of the local lithospheric mantle). The parallelism between these features and the main regional tectonic structures (transform faults and paleo-ridge axes) has been interpreted as evidence of a control of the structural inheritance of the oceanic lithosphere in the magma migration (Liuzzo et al., 2015). In this study, we focus on the seismic and volcanically active NW rift zone (NWRZ) on the western flank of Piton de la Fournaise, which has been interpreted as a sector of deep magma storage and potential lateral migration of magma towards the central and shallower plumbing system (Lénat et al., 2012, Liuzzo et al., 2015; Michon et al., 2015). The NWRZ is a 10-15-km-wide and 15-kmlong area displaying about 200 eruptive cones, some of which of recent (historical) age (Morandi et al., 2016). Our goal was to identify potential fluid/magma paths between the supposed deep storage zone below the western flank and the shallow central conduits. To do so, we obtained soil $\mathrm{CO}_{2}$ emission profiles taken from samples at high spatial resolution (sampling step of $20 \mathrm{~m}$ ) across the NWRZ, also collecting data on the $\mathrm{C}$-isotope signature of $\mathrm{CO}_{2}$ from selected samples. The spatial distribution of the gas samples with a clear magmatic contribution has been compared with the density distribution of dykes and with the spatial and depth distribution of recent micro-seismicity. Our findings have strong local implications, enabling a more solid reconstruction of a long-lived, though previously poorly defined, active preferential magma/fluid pathway, which in turn raises important issues concerning the local volcanic risk assessment of the densely populated western flank of Piton de la Fournaise volcano.

\section{Geological framework}

La Réunion is a 7-km-high (above sea floor), 200-km-wide intraplate volcanic island located in the Indian Ocean on an oceanic lithospheric block bounded by transform faults of the now extinct Mascarene Basin (Bernard and Munschy, 2000). The island is made up of two main volcanoes: Piton des Neiges (PdN) in the north-western part, which has been at rest for $\sim 20 \mathrm{ky}$ (Deniel et al., 1992); and Piton de la Fournaise (PdF), located in the south-eastern part of the island, is a current highly active basaltic shield volcano whose activity started at least 530 ky ago ( Gillot and Nativel, 1989). PdF is one of the world's most active volcanoes, averaging one eruption every nine months since 1930 (Peltier et al., 2009; Roult et al., 2012). Recorded observations since 1640 show that eruptions have been mostly restricted within the seawards oriented, horseshoe-shaped, open Enclos Fouqué caldera (Villeneuve and Bachèlery, 2006; Michon et al., 2013) whose formation occurred between 5465 and 2971 calendar years BP (Bachèlery, 1981; Upton et al., 2000; Ort et al., 2016). Seismic activity within this central area is restricted to a crustal depth range shallower than 8-9 km bsl (Battaglia et al., 2005; Michon et al., 2015). Former soil CQflux measurement campaigns, performed during a long period of rest of the volcano (2012-2014), have also evidenced a strong contrast between the low degassing zone close to its central area and the higher emissions on the volcano flanks (Liuzzo et al., 2015).

On the volcano flanks (outside the central area) both the distribution of old cinder cones of eccentric eruptions and high-level soil-degassing suggest the presence of three main active rift zones which radially cut the volcano massif and have been recognised as preferential for magma intrusion (Fig. 1; Bachèlery, 1981; Chevallier and Bachèlery, 1981; Villeneuve and Bachèlery, 2006; Bonali et al., 2011; Liuzzo et al., 2015; Michon et al., 2015, 2016). The two most active of these are the SE and NE rift zones (SERZ and NERZ), which have been interpreted as shallow lateral pathways of magma initially injected below the central area. Magmas erupted along the SERZ and NERZ display geochemical compositions similar to those erupted from the central area (Boivin and Bachèlery, 2009). In these sectors, recent flank eruptions have occurred every 50 years on average (Morandi et al., 2016) and have generally begun inside the Enclos Fouqué before lateral shallow magma migration (Villeneuve and Bachèlery, 2006). The SERZ and NERZ are thought to be closely linked to the central shallow plumbing system of Piton de la Fournaise and to result from the seawards displacement of the steep eastern flank (Bonali et al., 2011; Michon et al., 2015). On the aseismic SERZ and NERZ, Liuzzo et al. (2015) have reported high soil $\mathrm{CO}_{2}$ emissions, possibly defining a secondary deep magma transfer especially along recently active zones or/and possible tectonic structures oriented $\mathrm{N} 90^{\circ}$ cutting the western flank.

The third and largest rift zone, the NWRZ, has been characterised by peripheral eruptions for at least 29 ky (McDougall, 1971; Michon et al.,

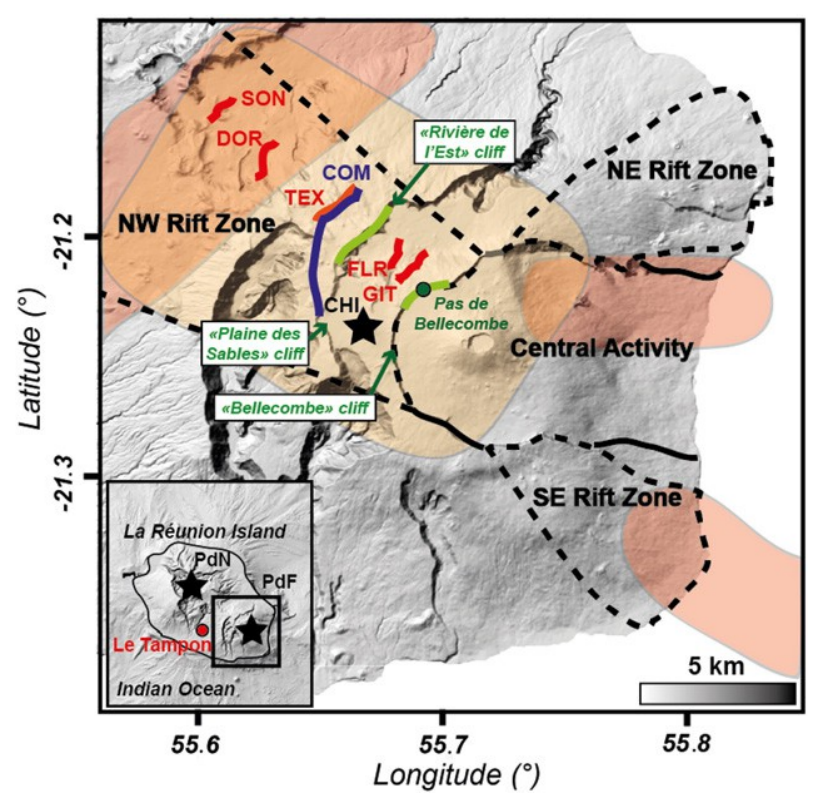

Fig. 1. Location map of the three active radial rift zones cutting the volcanic edfice of Piton de la Fournaise (La Réunion Island, Indian Ocean) and of diffuse soil G@mission profiles measured orthogonal to the main rift zone (NWRZ). Soil $\mathrm{CO}_{2}$ fluxes were measured with $40 \mathrm{~m}$-spacing on a long profile (COM; blue line) and with $20 \mathrm{~m}$-spacing on shorter subparallel profiles (GIT, FLR, TEX, DOR, SON; red lines). Green lines are cliffs investigated for dyke spatial distribution by photogrammetry. Colour filled sectors are areas where high soil $\mathrm{CO}_{2}$ fluxes and deep earthquakes are coupled (zones with hypocenters between 20 and $40 \mathrm{~km}$ (bsl) in red and between 11 and $20 \mathrm{~km}$ (bsl) in orange; Liuzzo et al., 2015; Michon et al., 2015). Seismicity shallower than $11 \mathrm{~km}$ (bsl) mainly occurs below the central cone (Enclos Fouqué) and is related to the shallow plumbing system of Piton de la Fournaise. $\delta^{13} \mathrm{C}$ analysis of $\mathrm{CO}_{2}$ trapped in fluid inclusions are from xenoliths found in Piton Chisny products (CHI, black star; Trull et al., 1993). 
2015) with, on average, one eruptive episode every 200 years (Morandi et al., 2016). The orientation of this large rift zone is interpreted as resulting from a control of the structural inheritance of the oceanic lithosphere in the magma propagation (Bachèlery, 1981; Chevallier and Bachèlery, 1981; Brenguier et al., 2007; Michon et al., 2007, 2015). Its development is linked to a regional NNE-SSW extension, which affected PdN since at least 2 my ago (Michon et al., 2015). The NW rift zone differs from the central area and related NE and SE rift zones for two main reasons: i) it is affected by seismic events with hypocenters deeper than the $10-12 \mathrm{~km}$ bsl crust-mantle boundary (Gallart et al., 1999), ii) it is characterized by the highest values of CQflux emissions on the volcano massif (Liuzzo et al., 2015). Geochemical studies revealed that the NWRZ is the site of deep magmatic processes occurring at mantle pressures (Kornprobst et al., 1984; Albarède et al., 1997; Bureau et al., 1998; Boudoire et al., in prep). Recent studies (Liuzzo et al., 2015; Michon et al., 2015) propose that NWRZ corresponds to the main pathway of lateral magma migration from the mantle source towards the central area, from a deep level marked by the sub-crustal seismicity.

Lateral migration of deep earthquakes below the NWRZ has been frequently recorded and is associated with major changes in eruptions activity or in eruptive intensity. During the 1992-1998 quiescent period, both lateral and upwards earthquakes migration was recorded since at least 1996 below the NWRZ at $16 \mathrm{~km}$ bsl with a spatiotemporal evolution towards the central area, leading to volcano reactivation and to the longlasting, large eruption of March 1998 (Battaglia et al., 2005). In 2007, an inverse downward and lateral migration of earthquakes was observed after the major caldera forming event of April 2007, when hypocenters beneath the central area deepened progressively down to $28-33 \mathrm{~km}$ bsl beneath the western flank of the volcano (Le Tampon in Fig. 1; Massin, 2009). This migration was interpreted as a propagating decompression of the plumbing system after a large volume eruptive event (González et al., 2013; Michon et al., 2015). After more than three years of rest (2011-2014), a distal seismic swarm at mantellic level occurred in March-April 2014, below La Plaine des Palmistes. It preceded the short-lived, small volume central eruption of June 2014 marking the beginning of a new eruptive period (Peltier et al., 2016; Boudoire et al., submitted).

\section{Methods}

Measurements of $\mathrm{CO}_{2}$ flux from the soil were performed using the "dynamic concentration method" (Gurrieri and Valenza, 1988; Camarda et al., 2006a). A 50-cm-long probe is inserted into the soil, connected to an IR spectrophotometer measuring a gas mixture between air and soil gas pumped at constant flux rate of $0.8 \mathrm{~L} / \mathrm{min}$. The soil $\mathrm{G} @ \mathrm{ux}$ is then estimated using an empirical relationship between $\mathrm{CO} \quad{ }_{2}$ dynamic molar concentration and $\mathrm{CO}_{2}$ fluxes:

FCQ $1 / 432-5: 8 k^{0: 24} C_{d}$ p 6:3 $k^{0: 6} C_{d}{ }^{3}$

where $\Phi \mathrm{CO}_{2}$ is the $\mathrm{CO}_{2}$ flux from the soil $\left(\mathrm{g} \mathrm{m}^{-2} \mathrm{~d}^{-1}\right), \mathrm{C}_{\mathrm{d}}$ the measured dynamic molar concentration, $\mathrm{k}$ is the soil permeability coefficient $\left(\mu \mathrm{m}^{2}\right)$ fixed here at 35 in accordance with previous studies on Piton de la Fournaise (Liuzzo et al., 2015 and references therein). Even if volcanic soil permeabilities can fluctuate (Moldrup et al., 2003; Camarda et al., 2006a, 2006b) due to heterogeneous soil properties and seasonal in fluence, this effect is here limited (1) by performing measurements during the dry season (Camarda et al., 2006b) and (2) due to the homogeneity of La Réunion Island soils above $1000 \mathrm{~m}$ asl referring essentially to andosols (Feder, 2013). Moreover Camarda et al. (2006a) have evidenced that considering a unique soil permeability value does not play a role on the statistical distribution of soil $\mathrm{CO}_{2}$ flux studies. Transects of measurement points were carried out orthogonally to the NWRZ. The longest one was a $6.5 \mathrm{~km}$-long profile across the NWRZ with a $40 \mathrm{~m}$ spacing between points. At various altitudes (1200-2200 $\mathrm{m}$ asl), shorter
(1.2-2 km-long) parallel profiles with $20 \mathrm{~m}$-spacing between points were performed in order to better define the shape and the dimensions of the main anomaly identified along the longer profile. This sampling strategy was guided by the difficulty in performing a regular mapping because of morphological obstacles (cliffs, lava field, lava flows, etc.) and vegetation cover. For comparison, the search for CQanomalies performed by Liuzzo et al. (2015) was performed with an average spacing of $100 \mathrm{~m}$. The reported profiles represent the best choice to obtain long and high-resolution measurements with a nearly constant spacing. Field measurements were carried out during the eruptive phase of August 2015, while the more proximal GIT profile was measured in May 15, 2015 during a sequence of earthquakes whose hypocentres showed a progressive upward migration below the central area (Lengliné et al., 2016), concomitant with $\mathrm{CO}_{2}$ enrichment in the summit fumaroles emissions (Peltier et al., 2016). Profiles were obtained during the dry season in order to limit environmental interference, consistent with previous studies. No rain occurred in the days before and during the measurements, and no significant changes of meteorological parameters were recorded. In addition, similarly to findings of Liuzzo et al. (2015), meteorological influence on $\mathrm{CQ}_{2}$ flux can be considered negligible during profile acquisition and not affecting the $\mathrm{CO}_{2}$ flux spatial distribution during the short duration of data measurements. Statistical analyses of the data distribution were performed using the graphical approach based on Sinclair's cumulative probability plots (MATLAB code; Sinclair, 1974). Thresholds were determined using the maximum-likelihood method based on a Gaussian Mixture Model (GMM) implementing an expectation-maximization (EM) algorithm developed on "Python" programming language, which is more accurate for short datasets (b 100 values; Elio et al., 2016). Isotopic analysis on gas samples collected in vials through a capillary probe into the soil (at $50 \mathrm{~cm}$-depth) was performed at INGV Palermo (Italy), with a Thermo Delta Plus XP CF-IRMS (precision $\pm 0.15 \delta \%$ ) coupled with a Thermo TRACE Gas Chromatograph (GC) and a Thermo GC/C III interface (Liuzzo et al., 2015).

Seismic events from 1996 to 2015 were recorded through the seismological network of the Observatoire Volcanologique du Piton de la Fournaise (OVPF-IPGP). In this study, we focus on earthquakes location within the NWRZ in order to analyse their eventual spatial correlation both with areas of anomalous soil $\mathrm{CO}_{2}$ fluxes and with the location of possible tectonic structures that act as preferential pathways for the upward migration of fluid/magma. For this reason, great attention has been paid to the spatiotemporal evolution of seismicity during the 2011-2015 period of transition from rest to volcanic reactivation. Most of the seismic events correspond to high-frequency and low-magnitude (M b 3) earthquakes. Furthermore, we determined the location of the dyke networks along the NWRZ by combining field observations and structure from motions that is a photogrammetric technique that produces Digital Elevation Models (DEM) through the processing of multi-stereoscopic photographs. A dataset of 88 oblique aerial photographs on the cliffs of Rivière de l'Est enabled the achievement of a high-resolution (25 pts $\mathrm{m}^{-2}$ ) 3D model in order to identify structures within these remote cliffs. The model was scaled and positioned using 10 Ground Control Points (GCP), with coordinates retrieved on a lower resolution ( $5 \mathrm{~m}$ ) DEM of the sector.

\section{Results}

\subsection{Soil CQfluxes}

The highest flux values were measured along the GIT profile, located closest to the volcano summit (Fig. 1). This profile, however, is the only one that was obtained in May 2015, when an important deep seismic swarm was recorded below the central area (Lengliné et al., 2016) and, when a significant $\mathrm{CO}_{2}$ enrichment was detected in the summit fumaroles (Peltier et al., 2016). Considering the time delay in the acquisition of soil $\mathrm{CO}_{2}$ data between GIT and other profiles (3 months), as well as the relatively long distance separating each profile (Fig. 1 ), we 
statistically analysed the whole dataset and each profile independently. Statistical analysis of the whole soil CQ flux dataset including 296 measurements reveals that the density distribution of $\mathrm{CO}_{2}$ fluxes is closer to log normal rather than to normal (Fig. A1, Appendix A) in agreement with previous works (Giammanco et al., 1998; Liuzzo et al., 2015). This allows recognizing possible populations partitioning of the data gathered both from the main profile and from the shorter ones. For this aim, a graphic analysis based on Sinclair's cumulative probability plots was performed on each dataset (Table 1; Fig. 2). On cumulative probability plots, inflection points reveal the presence of distinct populations (Sinclair, 1974). Populations were consequently quantified for each profile (Fig. 2; Table 1).

In the longest profile (COM; $6.5 \mathrm{~km} ; 40 \mathrm{~m}$-spacing), which spans most of the NWRZ, two populations were identified (Fig. 2; Table 1): one centered at $14 \mathrm{~g} \mathrm{~m}^{-2} \mathrm{~d}^{-1}$, which represents the majority of the dataset $\left(\Phi_{14} ; 82 \%\right)$, the second one centered at $140 \mathrm{~g} \mathrm{~m}^{-2} \mathrm{~d}^{-1}\left(\Phi_{140}\right.$; $2 \%)$. Other values are centered at $32 \pm 15 \mathrm{~g} \mathrm{~m}^{-2} \mathrm{~d}^{-1}\left(\Phi_{32} ; 16 \%\right)$ and are representative of various extents of mixing between the two de fined populations. In order to identify the values mostly de fined by the population of highest soil $\mathrm{CO}_{2}$ fluxes (contribution N 50\%), we have determined the corresponding threshold at $29 \mathrm{~g} \mathrm{~m}^{-2} \mathrm{~d}^{-1}$. In Table 2, we have thus reported three different groups: (1) the "background" group, defined by values where the population of lowest $\mathrm{CO}_{2}$ fluxes is preponderant (contribution N 50\%), (2) the "intermediate" group, set by values where the population of highest soil $\mathrm{CO}_{2}$ fluxes is preponderant (contribution N 50\%) and, (3) the "anomaly" group corresponding to the population of highest soil $\mathrm{CO}_{2}$ fluxes. Consequently, with this classification, it appears that the soil CQfluxes anomaly occurs in a narrow $140 \pm 20-\mathrm{m}$ wide zone within the profile (Fig. 3). Intermediate values are scattered and do not delimit such similar zone.

The application of Sinclair's approach to shorter profiles (GIT; TEX; DOR; SON; 1-2 km in length) suggests that they also show two soil $\mathrm{CO}_{2}$ flux populations (Fig. 2; Table 1). As for the case of the long transect, the lowest flux population is centered at $13-15 \mathrm{~g} \mathrm{~m}^{-2} \mathrm{~d}^{-1}$ and accounts also for most of the data (38-72\%). The highest one is centered at $86-$ $518 \mathrm{~g} \mathrm{~m}^{-2} \mathrm{~d}^{-1}$ and accounts for $7-10 \%$ of the data. This population range from 69 to $951 \mathrm{~g} \mathrm{~m}^{-2} \mathrm{~d}^{-1}$, i.e. above the $55 \mathrm{~g} \mathrm{~m}^{-2} \mathrm{~d}^{-1}$ threshold considered as representing the upper limit of the typical flux values from biological activity in the tropical conditions of La Réunion Island ( Liuzzo et al., 2015). A third population centered at $71 \mathrm{~g} \mathrm{~m}^{-2} \mathrm{~d}^{-1}$ and accounting for $13 \%$ of the dataset is only detected in the FLR profile (Table 1; Fig. 2). However, this population is scattered along the FLR profile and further investigations are required in order to exclude any artefact due to the restricted number of measurements carried out for the short transects. Following the previous classification performed for the long transect (COM), we are able to determine three groups of soil $\mathrm{CO}_{2}$ fluxes: (1) the "background" group defined by fluxes from 9 to $60 \mathrm{~g} \mathrm{~m}^{-2} \mathrm{~d}^{-1}$ consistent with biological activity, (2) the "intermediate" group with fluxes ranging from 20 to $309 \mathrm{~g} \mathrm{~m}^{-2} \mathrm{~d}^{-1}$ that overlap the moderate fluxes determined by Liuzzo et al. (2015); (3) the "anomaly" group defined by the highest fluxes (up to $951 \mathrm{~g} \mathrm{~m}^{-2} \mathrm{~d}^{-1}$ ).

Populations identified in this high-resolution survey of the NWRZ are consistent with previous results of Liuzzo et al. (2015) in their low-resolution survey of the volcano massif performed during a phase of volcano quiescence. The main differences are (1) the appearance of very high soil $\mathrm{CO}_{2}$ fluxes (up to $951 \mathrm{~g} \mathrm{~m}^{-2} \mathrm{~d}^{-1}$ ) close to the volcano central area (GIT), not detected during the volcano quiescence phase and, (2) the absence of similar very high soil $\mathrm{CO}_{2}$ flux (b117 $\mathrm{g} \mathrm{m}^{-2} \mathrm{~d}^{-1}$ ) in the distal area (SON) during the phase of volcano reawakening. Spatial representation of the soil $\mathrm{CO}_{2}$ fluxes groups also indicates that anomalous zones are often bordered by intermediate flux values (e.g. TEX, DOR), defining relatively narrow zones not exceeding $140 \pm 20 \mathrm{~m}$ of width, in each pro file (Fig. 4). As suggested above, we pointed out that performing such statistical analysis on the whole dataset prohibits the detection of potential soil $\mathrm{CO}_{2}$ anomalies on individual short profiles as observed for the SON transect (Table 1; Fig. 2).

\subsection{Carbon isotopic composition of $\mathrm{C}_{2} \mathrm{O}$}

For each profile, samples of gas were collected for carbon isotopic analyses in the sites that showed the highest relative emission rates, in order to put further constraints on the processes contributing to the

Table 1

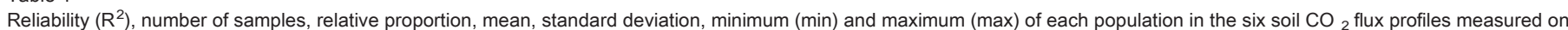

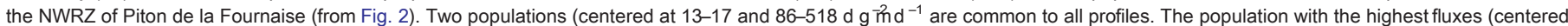

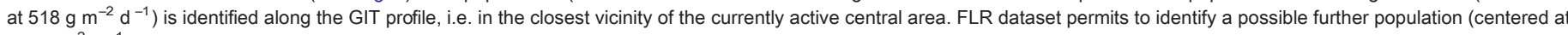
$71 \mathrm{~g} \mathrm{~m}^{-2} \mathrm{~d}^{-1}$ ).

\begin{tabular}{|c|c|c|c|c|c|c|c|c|}
\hline \multirow[t]{2}{*}{ Profiles } & \multirow[t]{2}{*}{ Populations } & \multirow[t]{2}{*}{$\mathrm{R}^{2}$} & \multirow[t]{2}{*}{ Number } & \multirow[t]{2}{*}{ Percentage } & \multicolumn{4}{|c|}{ Fluxes $\left(\mathrm{g} \mathrm{m}^{-2} \mathrm{~d}^{-1}\right)$} \\
\hline & & & & & Mean & Standard Deviation & Min & Max \\
\hline \multicolumn{9}{|c|}{ Total (this study) } \\
\hline \multirow[t]{4}{*}{ All } & Pop $\Phi_{14}$ & 0.92 & 153 & 52 & 14 & 3 & 9 & 20 \\
\hline & $\Phi_{75}$ & 0.94 & 131 & 45 & 75 & 64 & 22 & 294 \\
\hline & Pop $\Phi_{347}$ & 0.99 & 8 & 3 & 347 & 24 & 309 & 380 \\
\hline & Pop $\Phi_{856}$ & 1.00 & 2 & 1 & 856 & 134 & 762 & 951 \\
\hline \multicolumn{9}{|c|}{ Long profile (40 m-spacing) } \\
\hline \multirow[t]{3}{*}{ COM } & Рop $\Phi_{14}$ & 0.86 & 99 & 82 & 14 & 2 & 11 & 19 \\
\hline & $\Phi_{32}$ & 0.81 & 19 & 16 & 32 & 15 & 20 & 82 \\
\hline & Рop $\Phi_{140}$ & 1.00 & 3 & 2 & 140 & 20 & 119 & 160 \\
\hline \multicolumn{9}{|c|}{ Short profiles (20 m-spacing) } \\
\hline \multirow[t]{3}{*}{ SON } & Pop $\Phi_{13}$ & 0.89 & 33 & 72 & 13 & 2 & 9 & 17 \\
\hline & $\Phi_{34}$ & 0.96 & 10 & 22 & 34 & 11 & 20 & 56 \\
\hline & Pop $\Phi_{86}$ & 0.82 & 3 & 7 & 86 & 27 & 69 & 117 \\
\hline \multirow[t]{3}{*}{ DOR } & Pop $\Phi_{17}$ & 0.90 & 26 & 44 & 17 & 4 & 11 & 24 \\
\hline & $\Phi_{78}$ & 0.96 & 28 & 47 & 78 & 51 & 28 & 209 \\
\hline & Pop $\Phi_{295}$ & 0.86 & 5 & 8 & 295 & 59 & 244 & 373 \\
\hline \multirow[t]{3}{*}{ TEX } & Pop $\Phi_{14}$ & 0.89 & 41 & 56 & 14 & 2 & 11 & 19 \\
\hline & $\Phi_{53}$ & 0.89 & 27 & 37 & 53 & 41 & 20 & 160 \\
\hline & Pop $\Phi_{276}$ & 0.94 & 5 & 7 & 276 & 45 & 227 & 335 \\
\hline \multirow[t]{4}{*}{ FLR } & Pop $\Phi_{15}$ & 0.92 & 31 & 52 & 15 & 3 & 11 & 20 \\
\hline & $\Phi_{36}$ & 0.94 & 15 & 25 & 36 & 12 & 22 & 58 \\
\hline & Pop $\Phi_{71}$ & 0.91 & 8 & 13 & 71 & 3 & 67 & 74 \\
\hline & Pop $\Phi_{196}$ & 1.00 & 6 & 10 & 196 & 83 & 102 & 324 \\
\hline \multirow[t]{3}{*}{ GIT } & Рop $\Phi_{14}$ & 0.90 & 22 & 38 & 14 & 2 & 11 & 17 \\
\hline & $\Phi_{63}$ & 0.93 & 30 & 52 & 63 & 50 & 19 & 181 \\
\hline & Pop $\Phi_{518}$ & 0.82 & 6 & 10 & 518 & 270 & 309 & 951 \\
\hline
\end{tabular}



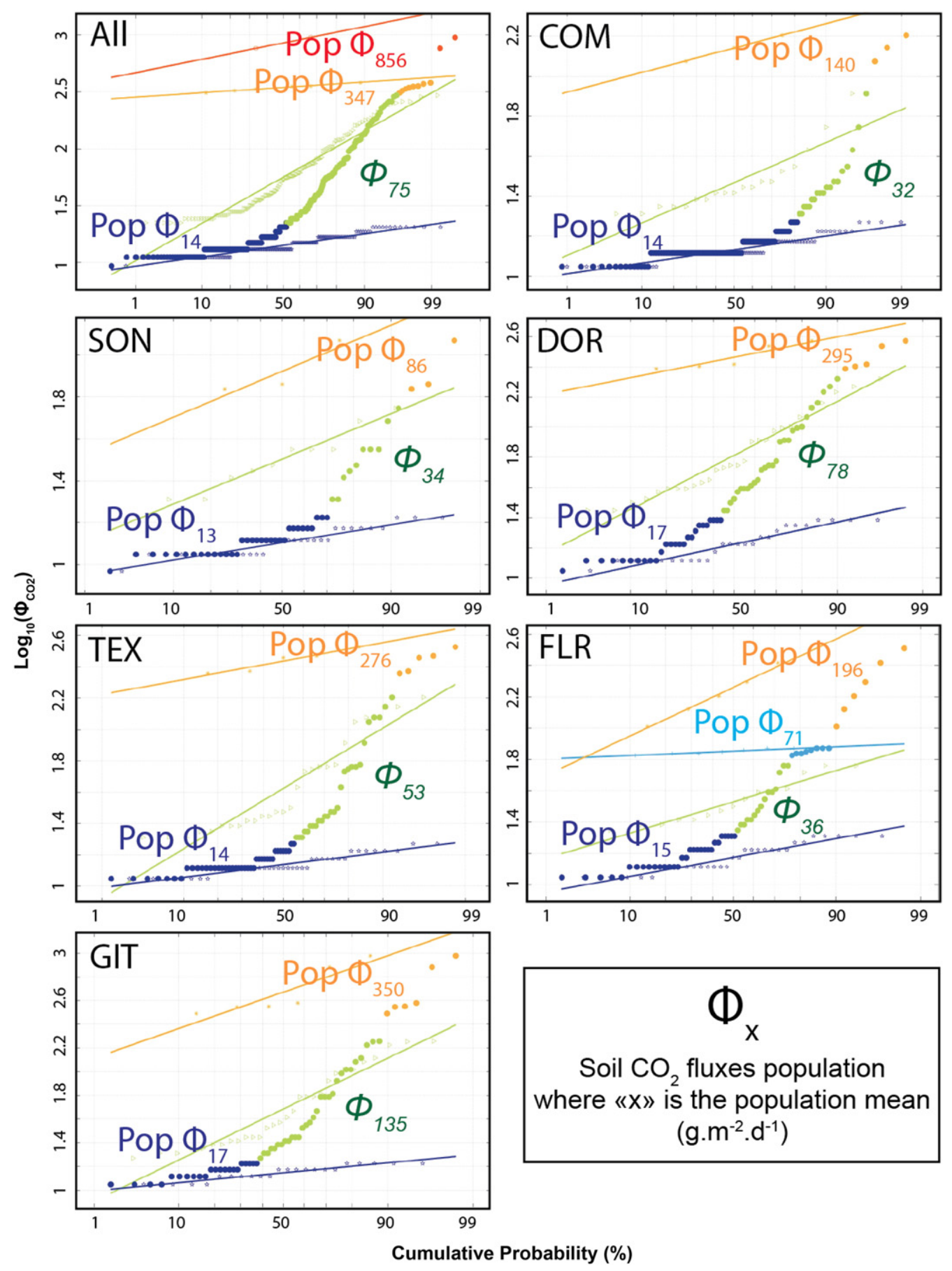

Fig. 2. Soil CQ flux populations identified using the graphical approach defined by Sinclair (1974) and based on probability plots. Each profile was processed independently to test for possible differences in background distributions in distant sites and in order to take into account that GIT profile was measured in May 2015,3 months before the other profiles. The mean of each population is reported on the graphs.

gas diffuse emissions (Table $\mathrm{A} 1$; Appendix $\mathrm{A}$ ). $\quad \mathrm{CO}_{2}$ concentration in analysed samples is consistent with field measurements and spans the range from 3986 to $52,618 \mathrm{ppm}(0.4-5.3 \%)$. In the following, we keep the original model of Liuzzo et al. (2015) where charcoal samples from Piton de la Fournaise ashes $(-24.7 \%$ on average) are chosen as representative of the biogenic end-member (Liuzzo et al., 2015; Morandi et al., 2016) and measurements in summit fumaroles $(-4.1 \%$ ) are considered representative of the magmatic $\delta{ }^{13} \mathrm{C}$ end-member (Marty et al., 1993). The signature of the magmatic end member is also consistent with results from crushing and step-heating analyses of olivine grains from Piton Chisny's xenoliths that range from $-4.6 \%$ up to $-3.7 \%$ o (Trull et al., 1993), with only one analysis at $-10.2 \%$. Our new isotopic data overlap with those previously measured on the volcano massif (Liuzzo et al., 2015) and range between $-24.2 \%$ and $-13.1 \%$ (Fig. 5). Regarding the whole dataset and following the previous statistical methodology, we have determined that the population de fined by the lowest $\delta^{13} \mathrm{C}$ range from -26.6 to $-22.2 \%$ and represents $42 \%$ of the dataset. The $4.4 . \%$ difference fully overlaps the theoretical difference predicted between carbon isotopic composition of carbon in soil $\mathrm{CO}_{2}$ and soil-respired $\mathrm{CO}_{2}$ (Cerling et al., 1991) and thus, it supports the assumption that $\delta^{13} \mathrm{C}$ values lower $-22.2 \%$ are best representative of the biogenic population. As already pointed out by Liuzzo et al. (2015), our data show the existence of an important mixing between magmatic and biogenic end-members. This signature is clearly identified in all soil çolux 
Table 2

Soil $\mathrm{CQ}_{2}$ fluxes clusters (background, intermediate, anomaly) from population determination (Table 1). Background soil $\mathrm{CQ}$ fluxes range from 9 to $60 \mathrm{~g} \mathrm{~m}^{-2} \mathrm{~d}^{-1}$. Intermediate soil $\mathrm{CO}_{2}$ fluxes range from 20 to $309 \mathrm{~g} \mathrm{~m}^{-2} \mathrm{~d}^{-1}$. Anomalous soil CQfluxes mainly reach 300 to $400 \mathrm{~g} \mathrm{~m}^{-2} \mathrm{~d}^{-1}$. Only the proximal GIT profile (performed in May 2015) displays very high fluxes up to $951 \mathrm{~g} \mathrm{~m}^{-2} \mathrm{~d}^{-1}$.

\begin{tabular}{|c|c|c|c|c|c|}
\hline \multirow[t]{2}{*}{ Profiles } & \multirow[t]{2}{*}{ Populations } & \multirow[t]{2}{*}{ Number } & \multirow[t]{2}{*}{ Percentage } & \multicolumn{2}{|c|}{$\begin{array}{l}\text { Fluxes } \\
\left(\mathrm{g} \mathrm{m}^{-2} \mathrm{~d}^{-1}\right)\end{array}$} \\
\hline & & & & Min & Max \\
\hline \multicolumn{6}{|c|}{ Long profile (40 m-spacing) } \\
\hline \multirow[t]{3}{*}{ COM } & Background & 111 & 92 & 11 & 29 \\
\hline & Intermediate & 7 & 6 & 29 & 119 \\
\hline & Anomaly (Pop $\left.\Phi_{140}\right)$ : & 3 & 2 & 119 & 160 \\
\hline \multicolumn{6}{|c|}{ Short profiles (20 m-spacing) } \\
\hline \multirow[t]{3}{*}{ SON } & Background & 33 & 72 & 9 & 20 \\
\hline & Intermediate & 10 & 22 & 20 & 69 \\
\hline & Anomaly (Pop $\left.\Phi_{86}\right)$ & 3 & 7 & 69 & 117 \\
\hline \multirow[t]{3}{*}{ DOR } & Background & 42 & 71 & 11 & 60 \\
\hline & Intermediate & 12 & 20 & 60 & 244 \\
\hline & Anomaly (Pop $\Phi_{295}$ ) & 5 & 8 & 244 & 373 \\
\hline \multirow[t]{3}{*}{ TEX } & Background & 57 & 78 & 11 & 42 \\
\hline & Intermediate & 11 & 15 & 42 & 227 \\
\hline & Anomaly (Pop $\Phi_{276}$ ) & 5 & 7 & 227 & 335 \\
\hline \multirow[t]{3}{*}{ FLR } & Background & 40 & 67 & 11 & 39 \\
\hline & Intermediate & 14 & 23 & 39 & 102 \\
\hline & Anomaly (Pop $\left.\Phi_{196}\right)$ & 6 & 10 & 102 & 324 \\
\hline \multirow[t]{3}{*}{ GIT } & Background & 38 & 66 & 11 & 41 \\
\hline & Intermediate & 14 & 24 & 41 & 309 \\
\hline & Anomaly (Pop $\Phi_{518}$ ) & 6 & 10 & 309 & 951 \\
\hline
\end{tabular}

populations, from the lowest to the highest soil $\mathrm{CO}_{2}$ flux (Fig. 6). In our dataset, the possible magmatic contribution did not exceed $50 \%$ even if the samples were carried out during an intense eruptive period (May 2015-August 2015). This signature is found in both distal (DOR, SON) and proximal (GIT) sites and, in both high fluxes (N227 $\mathrm{g} \mathrm{m}^{-2} \mathrm{~d}^{-1}$; GIT; TEX; DOR) and moderate fluxes (117 $\mathrm{g} \mathrm{m}^{-2} \mathrm{~d}^{-1}$; SON). Interestingly, measurements performed in 2013 on the same sites within the NWRZ, by Liuzzo et al. (2015), never exceeded $-22.4 \%$ except for those collected along GIT $(-16.8 \%)$. This is the first time that an increase of the magmatic contribution during volcano unrest has been documented in diffuse $\mathrm{CO}_{2}$ emissions at Piton de la Fournaise.

However, we stress that areas of high diffuse emission do not necessarily record a well-marked magmatic signature. Actually, a further analysis has been performed in order to compare the $\delta{ }^{13} \mathrm{C}$ data with the soil $\mathrm{CO}_{2}$ fluxes (Fig. 6). The correlation of $\delta{ }^{13} \mathrm{C}$ spatial distribution with high soil $\mathrm{CO}_{2}$ flux values within each profile (except FLR) allows distinguishing (1) high soil $\mathrm{CO}_{2}$ flux with a marked magmatic component and (2) high soil $\mathrm{CO}_{2}$ flux associated with a low $\delta{ }^{13} \mathrm{C}$ signature (Fig. 6). Such result evidences that even if various extents of mixing between magmatic and biological $\mathrm{CO}_{2}$ is a major process at Piton de la Fournaise, secondary processes could also affect the pristine ${ }^{1} \delta \mathrm{C}$ signature of such $\mathrm{CO}_{2}$ emissions.

\subsection{Seismicity}

Piton de la Fournaise experienced an unusually long period of quiescence in 2010-2014 followed by a still ongoing period of unrest with several eruptions per year since June 2014 (Peltier et al., 2016; Coppola et al., 2017). After the December 2010 eruption, seismic activity outside of the central area (essentially occurring within the upper mantle) was weak during 2011, 2012 and 2013 (Fig. 7a). In 2011, the few recorded seismic events were scattered below both La Plaine des Palmistes and La Plaine des Cafres (11-27 km bsl). Seismicity slightly increased in 2012 and most of the events (b10 events; 11-25 km bsl) were concentrated below La Plaine des Palmistes (Fig. 7b). In 2013, the area affected by most of the earthquakes shifted towards La Plaine des Cafres (17$27 \mathrm{~km} \mathrm{bsl}$ ). This seismicity distributed between Le Tampon and La Plaine des Palmistes occurred close to a previously proposed regional N30 $-40^{\circ}$ structure (Liuzzo et al., 2015; Michon et al., 2015).
During 2014, the location of the deep seismic events (mostly at 15$21 \mathrm{~km}$ bsl) shifted anew to La Plaine des Palmistes and drastically increased in March-April 2014 (Fig. 7c). Following this event, an increase of deep seismicity (19-28 km bsl) was recorded below the NWRZ in May-June 2014, evidencing a 3-4-km-wide, 9-km-long, and N130 trending seismic zone connecting La Plaine des Palmistes and the central area (Fig. 7c) close to the $\mathrm{N} 120^{\circ}$ regional structure (Liuzzo et al., 2015; Michon et al., 2015). Interestingly, similar increases in the number of deep seismic events were also recorded below the western flank of the volcano in 1996-1998 before the 1998-2010 eruptive period (Battaglia et al., 2005). Following this deep seismicity below the western flank, a new eruptive period started at Piton de La Fournaise with the 21th June 2014 eruption (Peltier et al., 2016). In 2015, Piton de la Fournaise produced four eruptions (4-16th February 2015, 17-30th May 2015, 31th July-2nd August 2015 and 24th August-31th October 2015) associated with shallow (crustal) seismic events (b $9 \mathrm{~km} \mathrm{bsl}$ ) below the central cone (Fig. 7a). In parallel, 2015 deep seismicity continued to remain relatively frequent below the $\mathrm{N} 130^{\circ}$ trending seismic zone $(17-21 \mathrm{~km} \mathrm{bsl})$ and below Le Tampon (27-28 km bsl).

\subsection{Distribution of intrusive dykes on PdF}

With the exception of Pas de Bellecombe, along the Enclos Fouqué scarp, no major dyke networks were observed on the cliffs of Plaine des Sables and Bellecombe cutting the NWRZ (Fig. 1). We consequently focused our analysis on the cliff of the Rivière de l'Est in order to further constrain magma paths and the distribution of vertical discontinuities for percolation of $\mathrm{CO}_{2}$-rich fluids on the western volcano flank. Photogrammetric measurements performed on this cliff showed a series of 14 dykes of unknown age organized in two groups with orientations ranging between $\mathrm{N} 125^{\circ}$ and $\mathrm{N} 150^{\circ}$ (Fig. 8). In the southwestern part of the cliff, the first group is made of the thickest dykes (up to $5 \mathrm{~m}$-thick) with a $\mathrm{N} 140( \pm 10)^{\circ}$ average orientation (Fig. 8a). The second group is composed of thinner dykes (1-2 $\mathrm{m}$ in thickness) and is clearly visible in the cliff $\sim 570 \mathrm{~m}$ northeast of the first group (Fig. 8b). Interestingly, the most recent peripheral eruptive cones on the western flank (1401465 yrs. BP; Morandi et al., 2016) are aligned with this second group and with a rare well-exposed, $1.3 \mathrm{~m}$-thick, $\mathrm{N} 135( \pm 10)^{\circ}$ trending dyke cropping out in the Bellecombe cliff. Finally, one isolated dyke is also found in the northeastern part of the cliff, about $300 \mathrm{~m}$ from the previous ones (Fig. 8c). Some dykes might not have been identified by our analysis owing to the dense vegetal cover, which may mask their morphological signature. However, our observations show that is the most important concentration of dykes within the NWRZ.

\section{Discussion}

\subsection{Significance of the CQanomalies}

Our survey of soil $\mathrm{CQ}_{2}$ flux evidences the occurrence of high soil $\mathrm{CQ}_{2}$ emission zones with variable $\delta{ }^{13} \mathrm{C}$ signatures. We have differentiated along a same transect, sites (1) with high soil Coflux and a high isotopic signature and those (2) with high soil $\mathrm{CQ}_{2}$ flux and low isotopic signature (Fig. 6; Table A1, Appendix A). However, the identification of such high $\mathrm{CO}_{2}$ emission zones with low $\delta{ }^{13} \mathrm{C}$ signatures highlights that some parts of the transects could diverge from a simple magmatic-biogenic mixing approach, as developed in this study.

On one side, isolated high soil CQ fluxes only detected on one point with respect to surrounding measurements (e.g. GIT on Fig. 6) could reflect local enrichment in organic matter as supported by their low $\delta{ }^{13} \mathrm{C}$ signature (Basile-Doelsch et al., 2007; de Junet et al., 2013). On another side, high soil $\mathrm{CO}_{2}$ fluxes defining a wide zone is more prone to track a real magmatic contribution, the $\delta^{13} \mathrm{C}$ signature being affected by secondary processes. Actually, CQeaction with cold groundwater can be an efficient process to explain such fractionation $\left(\Delta{ }^{13} \mathrm{C}\right.$ between -8.5 and $-9.4 \%$ at $10-25^{\circ} \mathrm{C}$; Mook et al., 1974; Giammanco et al., 1998; 


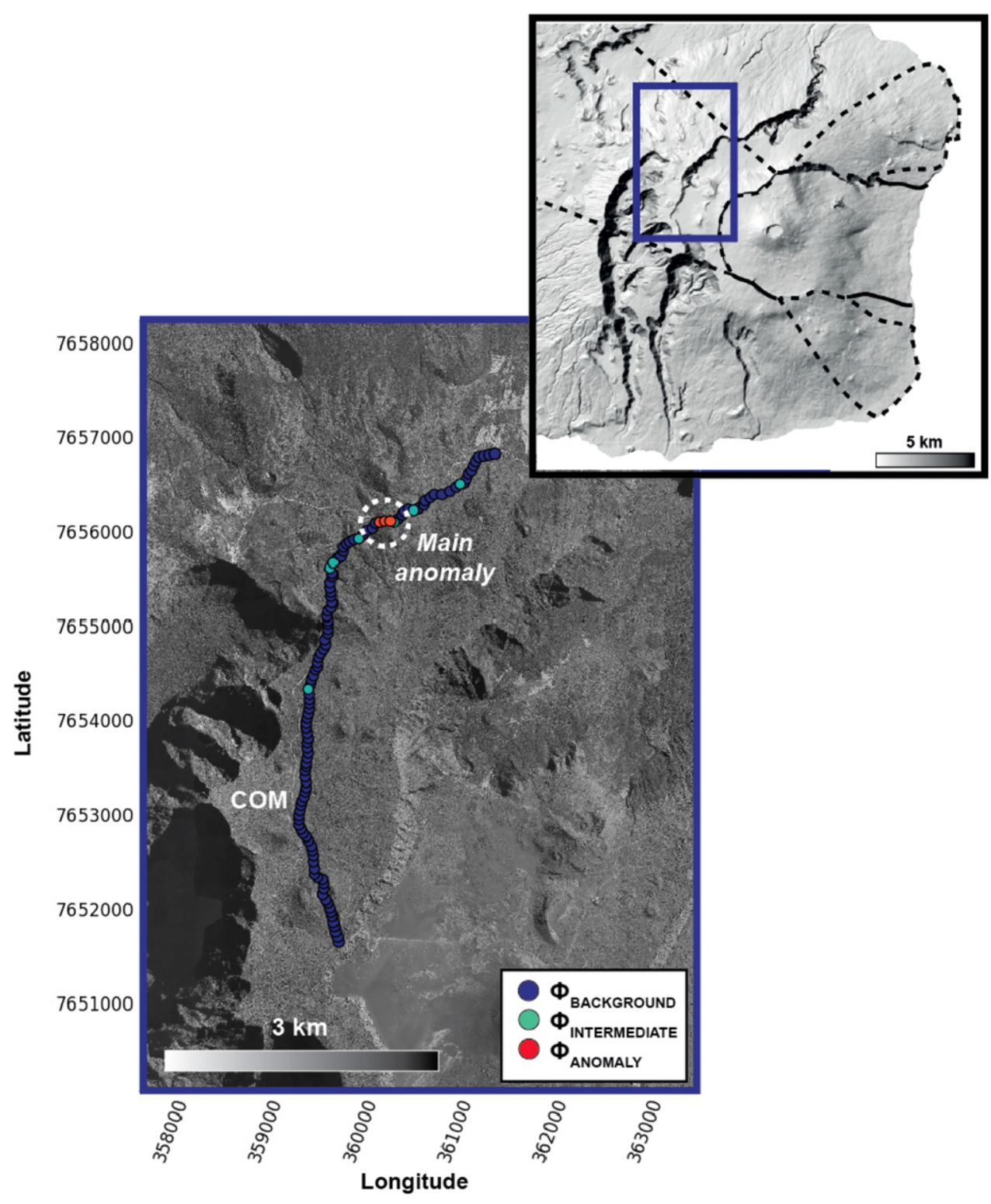

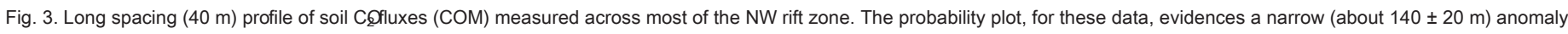
of moderate diffuse $\mathrm{CO}_{2}$ soil emissions.

Chiodini et al., 2008). This effect can be particularly marked in the tropical environment of Piton de la Fournaise, where the high annual rainfall creates an aquifer whose thickness is far from negligible. At Piton de la Fournaise, the water table forms a dome across the island following discontinuities between young and old geological units (Folio, 2001; Join et al., 2005) whose permeability to water is highly contrasting. This model known as the Canarian-type conceptual model of groundwater ( Join et al., 2005 and references therein) contrasts with basal water tables as observed at Hawaii (USA). Consequently, an important hydraulic gradient exists from the highest elevated zones inside the island towards the lowest coastal zones where basal aquifers predominate. Such water circulation within the volcanic edifice, unlike stable permanent aquifers, is potentially less prone to produce important carbon fractionation processes at large kilometric scale. However, the presence of punctual water-saturated zones could favor such fractionation processes. For instance, low $\delta{ }^{13} \mathrm{C}$ values were measured in pluridecametric zones of high soil $\mathrm{CO}_{2}$ fluxes along the FLR and DOR transects (Fig. 6). As a matter of fact, in our study, these sectors are the only ones set in the vicinity of water outlets and river beds (blue arrows on Fig. 9). This process can thus contribute to hide the pristine magmatic signature of high soil $\mathrm{CO}_{2}$ diffuse emissions.

\subsection{Identification of volcano-tectonic structures}

Many recent studies used soil $\mathrm{CO}_{2}$ diffuse emissions as a useful and unambiguous tracer of volcanic and tectonic structures (Azzaro et al., 1998; Giammanco et al., 1998; Finizola et al., 2003, 2004; Revil et al., 2008, 2011; Bennati et al. , 2011; Bonforte et al., 2013). In this study of the NWRZ of Piton de la Fournaise, we adopted a multidisciplinary approach combining (1) soil $\mathrm{CO}_{2}$ flux and isotopic data, (2) seismic events spanning from 1996 to 2015, (3) a photogrammetric model to quantify the dyke distribution and orientation and, finally, (4) the spatial density of the cinder cones in the area investigated, with the aim of identifying and better constraining potentially active structures within this rift zone. Fig. 9 summarizes the different data used in the current study and clearly suggests the existence of a linear structure in the NWRZ. 


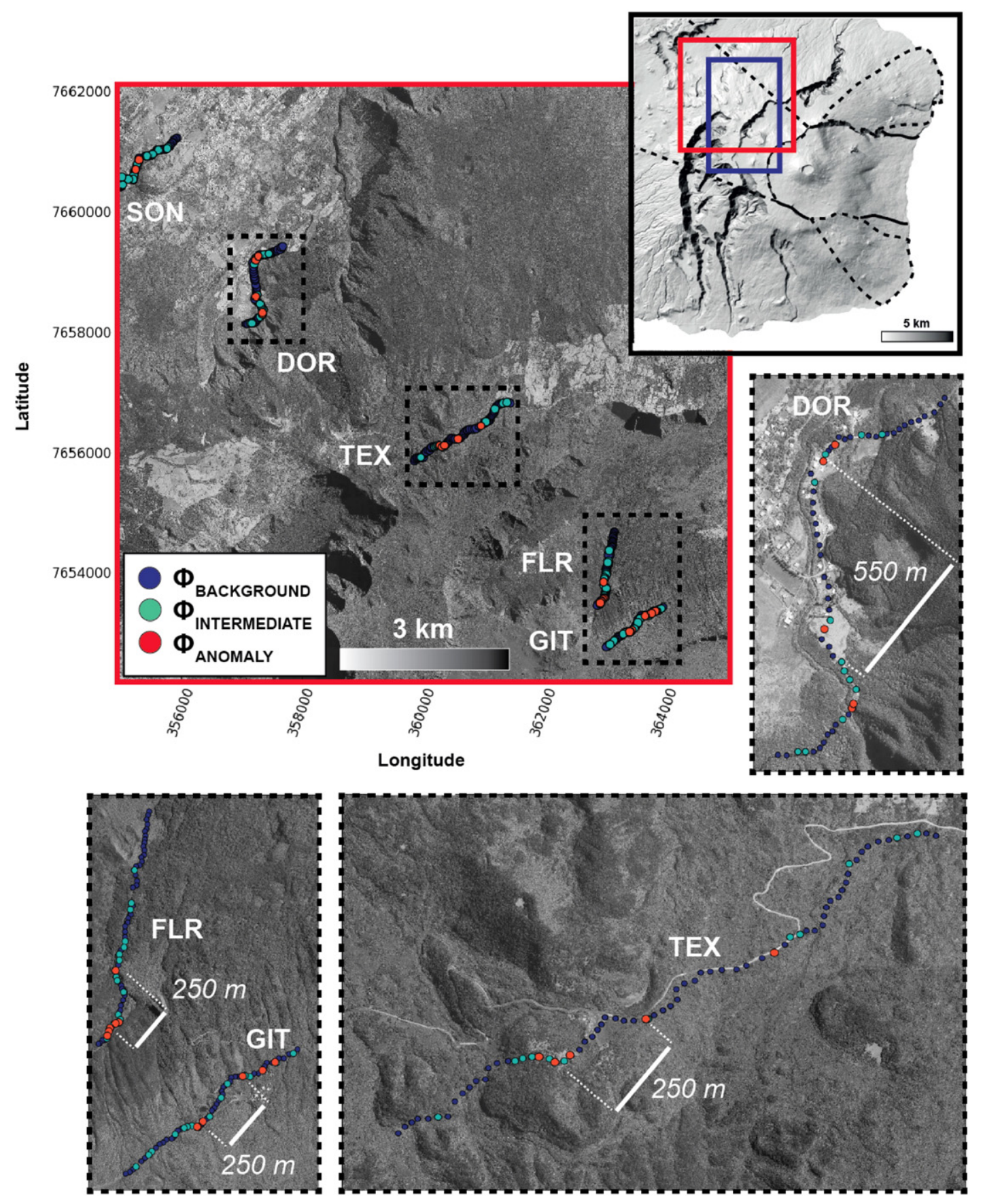

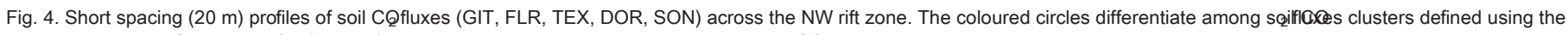

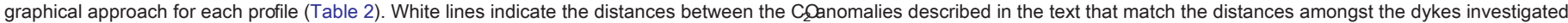
(see the text and Fig. 8).

Firstly, the zones of soil CQemission with a more pronounced magmatic isotopic signature are well aligned with a $\mathrm{N} 135^{\circ}$ orientation. Secondly, such an orientation is similar to those of the dyke networks within the cliffs of Rivière de l'Est and Bellecombe. It is worth noting that spacing between dyke groups (Fig. 8) is quite consistent with the spacing separating soil $\mathrm{CO}_{2}$ anomalies on a parallel axis within individual profiles (Fig. 4): (1) $550 \mathrm{~m}$ in DOR with respect to the $570 \mathrm{~m}$ between dykes groups 1 and 2 and; (2) $250 \mathrm{~m}$ in GIT, FLR and TEX pro files in comparison with the $300 \mathrm{~m}$ spacing between dykes groups 2 and 3 . Thirdly, the most recent (470 $\pm 75-1466 \pm 75 \mathrm{BP})$ peripheral eruptive cones of the NWRZ (Petit Cratère in the NW to Formica Leo in the SE) show an alignment spatially superimposed onto the soil $\mathrm{CO}_{2}$ anomalies and dyke networks.
Fourthly, most of the seismic hypocenters recorded between 2013 and 2015 (and in particular between 2014 and 2015) below the NWRZ were concentrated along a 3-4-km-wide, 9-km-long, $\quad \mathrm{N} 130^{\circ}$-oriented corridor at the vertical of the identified structure. Interestingly, their increasing number was coeval with the reactivation of the central volcano. Finally, lavas of some of the recent peripheral cones widespread above this seismically active zone record higher pressures (2-7 kbar) than the central area (Bureau et al., 1998; Boudoire et al., in prep). Our dataset thus suggests that an important and still active deeply-rooted structure (at least 11-km-long), identified here for the first time as the Songit - Lineament, channels fluid transfer across the western flank of Piton de la Fournaise without undergoing major secondary interactions (Fig. 9). 


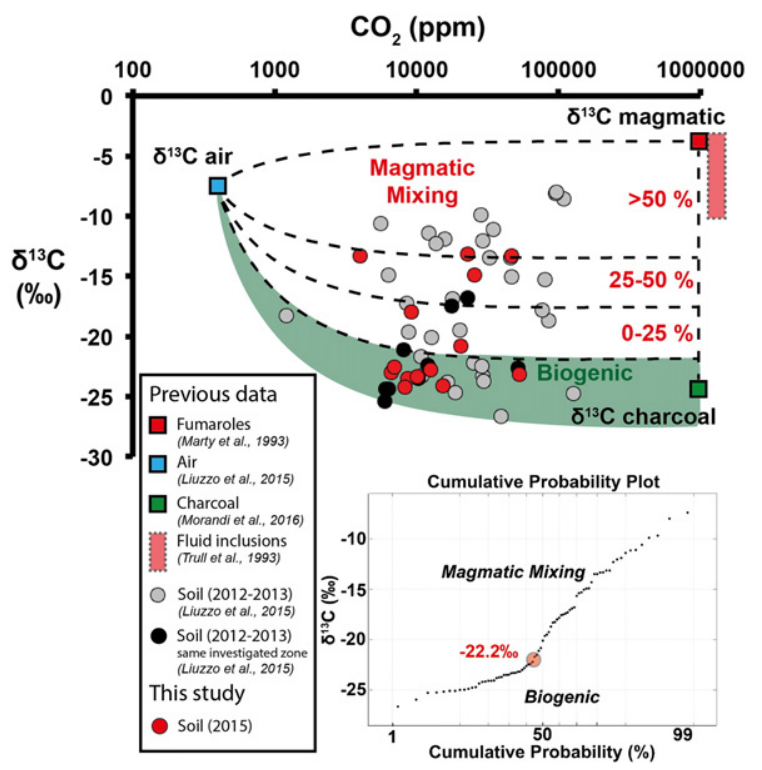

Fig. 5. Diagram plotting carbon isotopic composition of $\mathrm{CO}_{2}(\%)$ from the soil versus the corresponding $\mathrm{CO}_{2}$ log-concentrations (ppm) at PdF. New data acquired on the NWRZ overlap the previous results from $\mathrm{CO}_{2}$ samples collected on the whole volcano area. The biogenic threshold (-22.2\%) was determined by a statistical graphical approach (Sinclair, 1974). A potential contribution of magmatic fluids (up to $50 \mathrm{wt} \%$ ) is thus identified in both high and low flux populations highlighting the magmatic component of some anomalous sectors of diffuse soil $\mathrm{CO}_{2}$ emissions. Dashed lines represent mixing between different $\mathrm{CO}_{2}$ sources. It is noteworthy that the isotopic data from the same points sampled both in 2012-2013 and in 2015 show a significant increase in magmatic contribution during 2015 (red circles) differently from what happened during the 2012-2013 period (black circles).

\subsection{Origin of the Songit lineament}

Two main orientations, $\mathrm{N} 30-40^{\circ}$ an $\mathrm{N} 120-130^{\circ}$, are identified in volcano-tectonic structures of La Réunion and are thought to originate from a control of the structural inheritance of the oceanic lithosphere on the magmatic-tectonic evolution (Chevallier, 1979; Michel and Zlotnicki, 1998; Michon et al., 2007). In this general setting, the existence of a deep lithospheric, $\mathrm{N} 30^{\circ}-40^{\circ}$ trending structure, orthogonal to the elongation of La Réunion island, has been proposed based on the distribution both of the deepest seismicity (i.e. deeper than $20 \mathrm{~km}$ bsl on average and deeper than $25 \mathrm{~km}$ bsl below Le Tampon; Fig. 10a,b) and of the highest soil CQ fluxes (Liuzzo et al., 2015; Michon et al., 2015). This zone is located between the edifices of Piton de la Fournaise and Piton des Neiges. It was characterized by a weak seismic activity between 2011 and 2013, during a period of rest of Piton de la Fournaise, and by a striking increase in strain release in 2014, before the volcano reawakening. Hypocenters during the 2014 seismic crisis below La Plaine des Palmistes were concentrated at depth ranging between 15 and $21 \mathrm{~km}$ bsl $(18 \mathrm{~km}$ bsl on average; Fig. 10b) and were located close to the limit of the 'petrological' Moho defined by the underplating layer below the Indian oceanic crust (Gallart et al., 1999; Fontaine et al., 2015; Michon et al., 2015; Boudoire et al., in prep). The southern end of this seismic zone is spatially connected to the $\mathrm{N} 135^{\circ}$ Songit Lineament, whose hypocenters depths are about $5 \mathrm{~km}$ greater on average, ranging between 19 and $28 \mathrm{~km}$ bsl. Contrary to the seismicity below La Plaine des Palmistes, the 2014 seismicity along

Fig. 6. Profiles of diffuse $\mathrm{CO}_{2}$ soil emissions and their corresponding isotopic carbon composition. Filled colour zones represent flux clusters defined previously with the same colour code used in Fig. $\quad 4 . \delta^{13} \mathrm{C}$ above $-22.2 \%$ is interpreted as the result of mixing in variable proportions (up to $50 \%$ ) between magmatic and organic (M-B) CO sources. $\delta^{-13} \mathrm{C}$ below $-22.2 \%$ is considered purely biogenic (B). Note that the weak $\mathrm{CO}_{2}$ emissions have a clear biogenic signature, while spots of high soil $\mathrm{CO}_{2}$ flux can have both a high or low $\delta{ }^{13} \mathrm{C}$ signature.

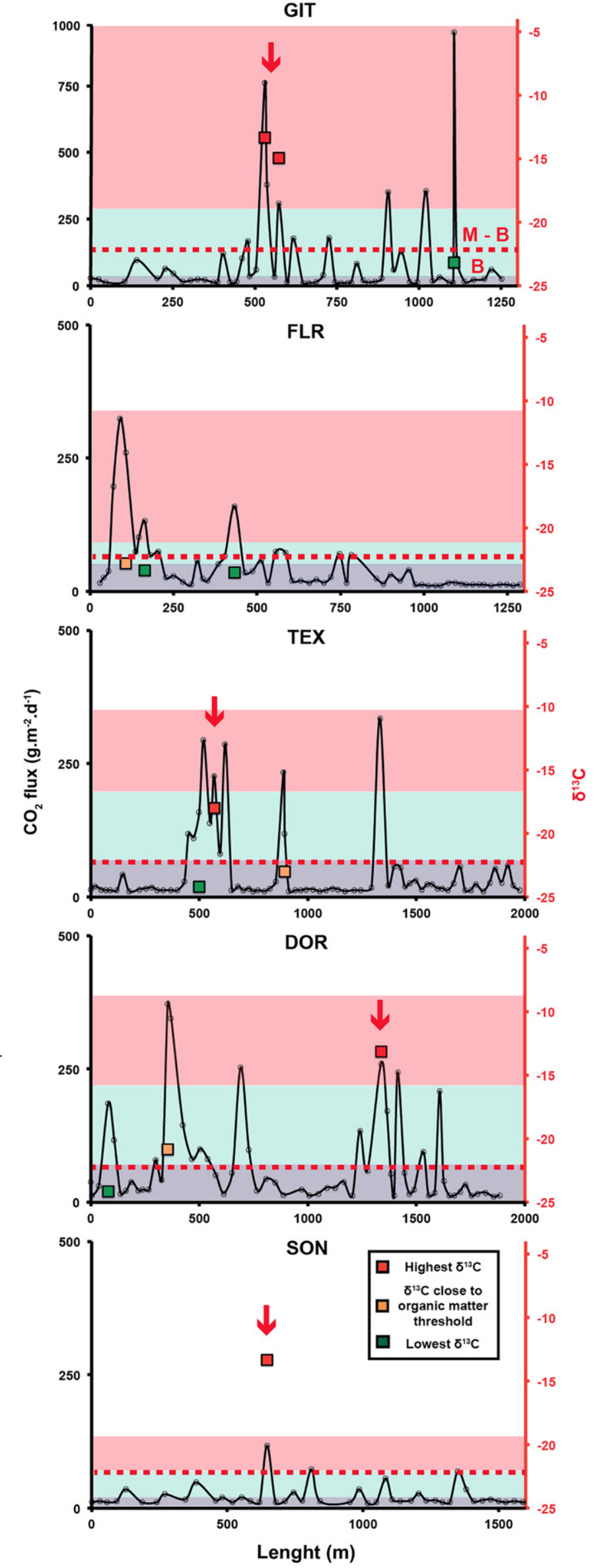



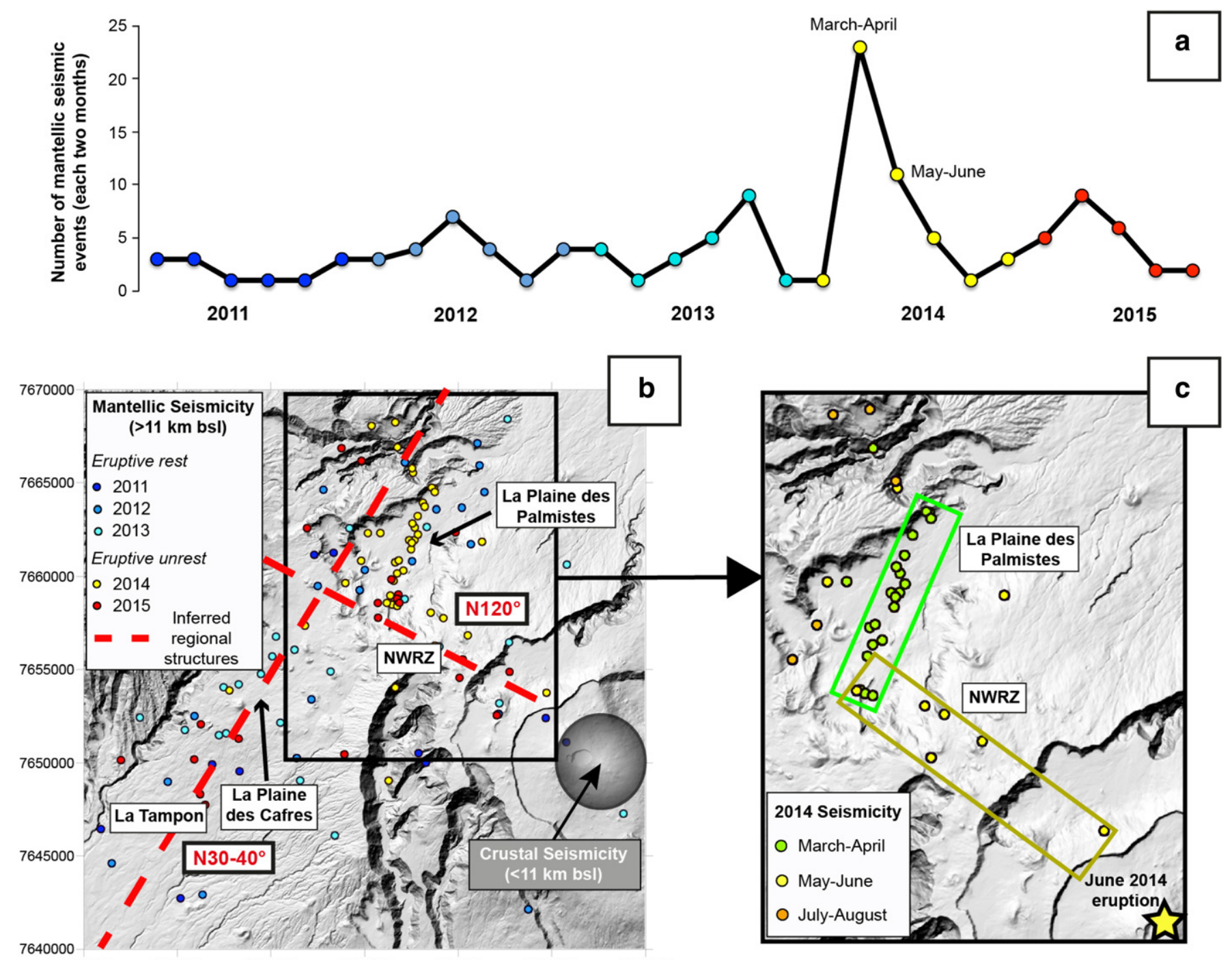

Fig. 7. (a) Temporal evolution of the number of seismic events below the western flank of the volcano at mantellic level, between 2011 and 2015 (each two months). (b) Seismic hypocenters (dots) during the rest period (2011-2013) and the unrest activity (2014-2015) marking the beginning of a new eruptive period (Peltier et al., 2016). Red dashed lines

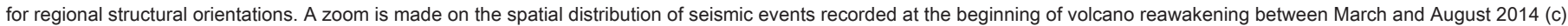

the Songit Lineament was less frequent and horizontally and vertically scattered along a $\mathrm{N} 130^{\circ}$ oriented corridor within the mantle lithosphere (Fig. 10c).

Considering all our observations, we propose the following interpretation for the origin of the Songit Lineament. First, the precise linear correspondence in the space among soil $\mathrm{CO}_{2}$ anomalies, despite an elevation difference of $1000 \mathrm{~m}$ between the most extreme pro files located NW (SON) and SE (GIT) of the study area, suggests a vertical to sub-vertical dip of the structure draining $\mathrm{CO}_{2}$ through the edifice. This vertical geometry is also supported by the spatial correspondence between the area of soil gas anomalies at the surface and the seismic corridor (Fig. 10c). Assuming a dip of $30^{\circ}$ for the proposed gas-leaking tectonic structure (dip of a neoformed normal fault in the extensive regional stress field of La Réunion) would produce a lateral shift of $6 \mathrm{~km}$ between the top of the seismic zone (10 km bsl) and the soil $\mathrm{CO}_{2}$ anomalies. Second, in a volcanic setting the nature of the vertical structure could correspond to magma intrusions or faults. Combining the results of a petrological analysis (magmas feeding the recent eruptive cones along the Songit Lineament with a record of high-pressures fluid inclusions in crystals, compatible with sub-crustal-to-mantle depth sources; Boudoire et al., in prep) and the occurrence of the soil $\mathrm{CO}_{2}$ flux emissions atop a dyke network, we propose that the fluids along the Songit
Lineament are primarily drained by dykes cutting the oceanic crust and the edifice. At depth greater than that of the oceanic crust, seismic data indicate the existence of a seismically active sub-vertical zone extending vertically from 28 to $11 \mathrm{~km}$ bsl. Unfortunately, our data do not allow us to decipher the nature of such a deep structure. It can, therefore, only be speculated that this could correspond to a combination of subvertical faults and magma intrusions within the mantle lithosphere. We finally propose that the orientation of the Songit Lineament, which is almost constant from depth $\left(\mathrm{N} 130^{\circ}\right)$ to surface $\left(\mathrm{N} 135^{\circ}\right)$, and roughly parallel to that of regional structures (paleo-ridges) around La Réunion (Lénat et al., 2001; Michon et al., 2007), is controlled by the reactivation of lithospheric structures under a persistent weak extensional stress field with a horizontal NNE-SSW-directed minimum principal stress $\sigma_{3}$. This would permit intermittent magma ascent directly from the deep plumbing system that is subsequently followed by fluids up to the surface.

\subsection{Magma/fluid transfer along the Songit lineament}

The deepest part of the plumbing system feeding the activity of Piton de la Fournaise ( $\mathrm{N} 11 \mathrm{~km}$ bsl) is considered shifted to the northwest relative to the most active volcanic central area (Liuzzo et al., 2015; Michon 


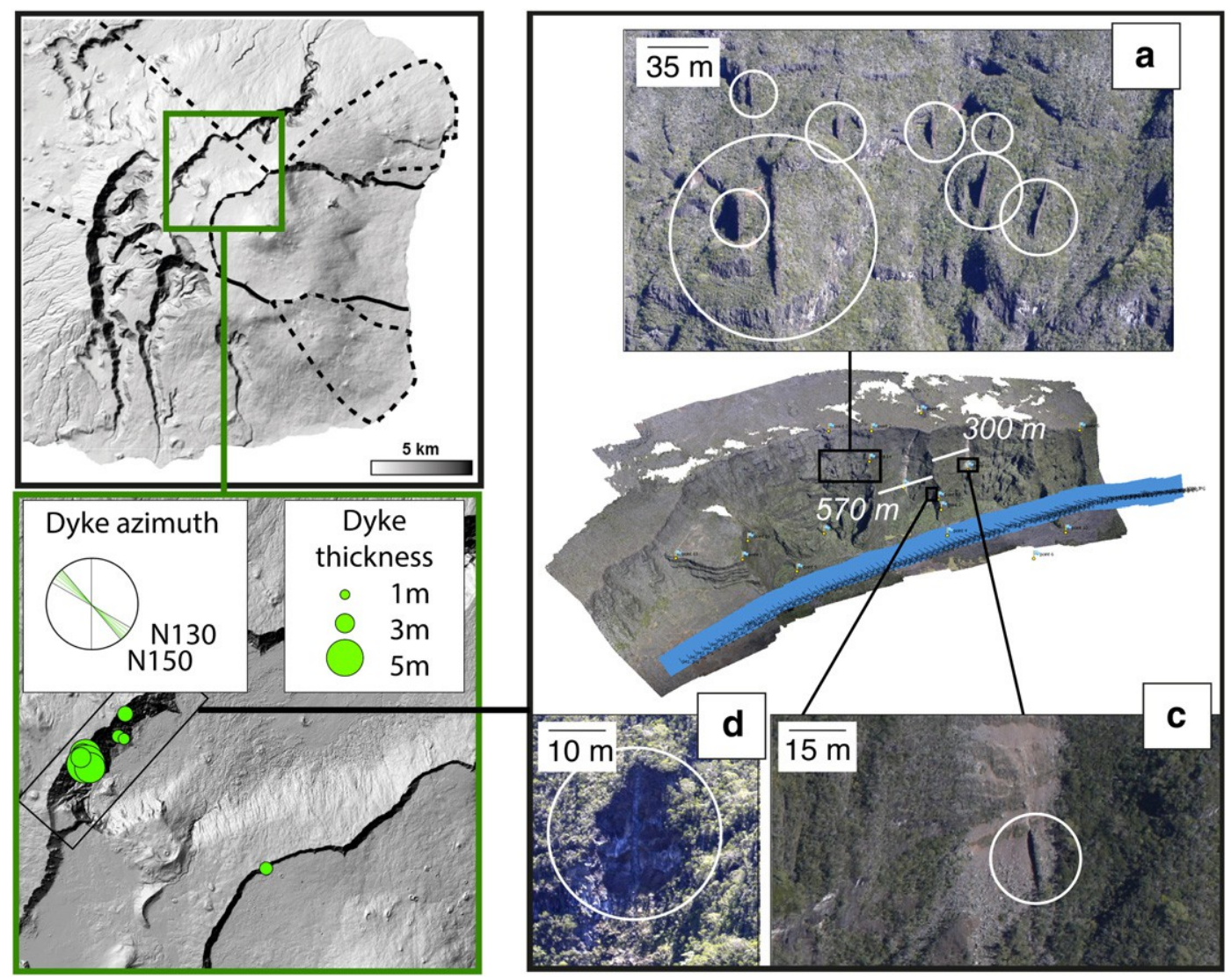

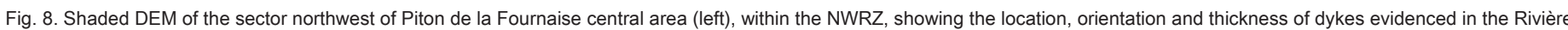
de l'Est cliff and the Bellecombe cliff. Related 3D model (right) of Rivière de l'Est cliff, with insets showing details of the dyke concentration zones.

et al., 2015). A similar lateral offset is not uncommon at other basaltic volcanoes, as it was deduced also at Mount Etna (Patanè et al., 2013), at Kilauea (Wright and Klein, 2006) or at El Hierro during the last 2011-2012 eruption (López et al., 2012; González et al., 2013). Michon et al. (2015) integrated seismic, volcanological and petrological data to propose that magma undergoes multistep laterally shifted migration from a deep mantle source at ca. $30 \mathrm{~km}$ bsl located between PdF and $\mathrm{PdN}$ edifices towards shallower depths of $\quad 15-20 \mathrm{~km}$ bsl along the NWRZ. There, magma transport can occur at the depth of crustal underplating, corresponding to a major zone of magma accumulation. This depth range is consistent with the fact that $\mathrm{N} 50 \%$ of $\mathrm{CO}_{2}$ initially dissolved in primitive magmas of Piton de la Fournaise is exsolved at $400 \mathrm{MPa}$, i.e. around $15 \mathrm{~km}$ (bsl) (Papale, 1999; Moretti and Papale, 2004; Papale et al., 2006; Di Muro et al., 2016) and thus can be released across the western flank of the volcano along preferential structures such as the Songit Lineament (Fig. 10c).

Our new multidisciplinary dataset confirmed a geometrical link between the deep system located below La Plaine des Palmistes and La Plaine des Cafres, and the shallow plumbing system below the central area. Moreover, the succession of events that preceded the reawakening of Piton de la Fournaise in June 2014 also suggests a direct structural link between the two systems. Indeed, the seismicity that appeared in March-April 2014 below La Plaine des Palmistes, shifted along the Songit Lineament in May 2014 until the reawakening of Piton de la Fournaise in June 2014. Importantly, the seismicity increase in March-April 2014 was coeval with a strong increase of soil $\mathrm{CO}_{2}$ flux in La Plaine des Cafres and La Plaine des Palmistes (Boudoire et al., submitted). This major detected soil $\mathrm{CO}_{2}$ anomaly was interpreted as resulting from a deep magmatic event at mantellic level refilling the central shallow plumbing system and resulting in the reawakening of the volcano since June 2014. We thus hypothesize that magma overpressure at a depth $\mathrm{N} 21 \mathrm{~km}$ bsl (maximum depth of seismic events in March-April 2014) in the deep plumbing system, below La Plaine des Palmistes was followed by a lateral propagation towards the shallow plumbing system in the central area. This in turn led to the reactivation of active structures in March-June 2014 prior to the June 2014 eruption.

Interestingly, a recent petrological study of peripheral eruptive cones within the NWRZ (Boudoire et al., in prep) highlights that some of their recent eruptive products are geochemically comparable to the eruptive products currently emitted by in central area. These authors propose the existence of punctual lateral magmatic migrations at crustal levels from the central area towards the NWRZ, along the Songit Lineament (Fig. 9). All these results consequently imply that the Songit Lineament represents an active preferential magma path not only from the deep plumbing system to the shallow one, but also from the central area to the NWRZ. The age of the peripheral cones along this lineament (Petit Cratère: $470 \pm 75$ BP. Piton sous le Gîte: $1466 \pm$ 75 BP; Morandi et al., 2016) suggests that this structure has been active since at least $1500 \mathrm{BP}$. The high density of peripheral eruptive cones along this structure (Fig. 9) and up to Piton des Songes (SON profile) highlights the important extension of this preferential magmatic path, reaching La Plaine des Palmistes where N 5000 inhabitants live (INSEE 2011).

\section{Conclusions}

A high resolution survey of soil diffuse $\mathrm{CQ}$ emissions was carried out on the North West Rift Zone (NWRZ) of Piton de la Fournaise, across its western flank. Narrow zones of high soil CQfluxes with a clear magmatic isotopic signature are well aligned with seismic epicentres detected during the recent (2014-2015) phase of reawakening of the volcano after a long lasting phase of rest. Moreover, this alignment (here called 


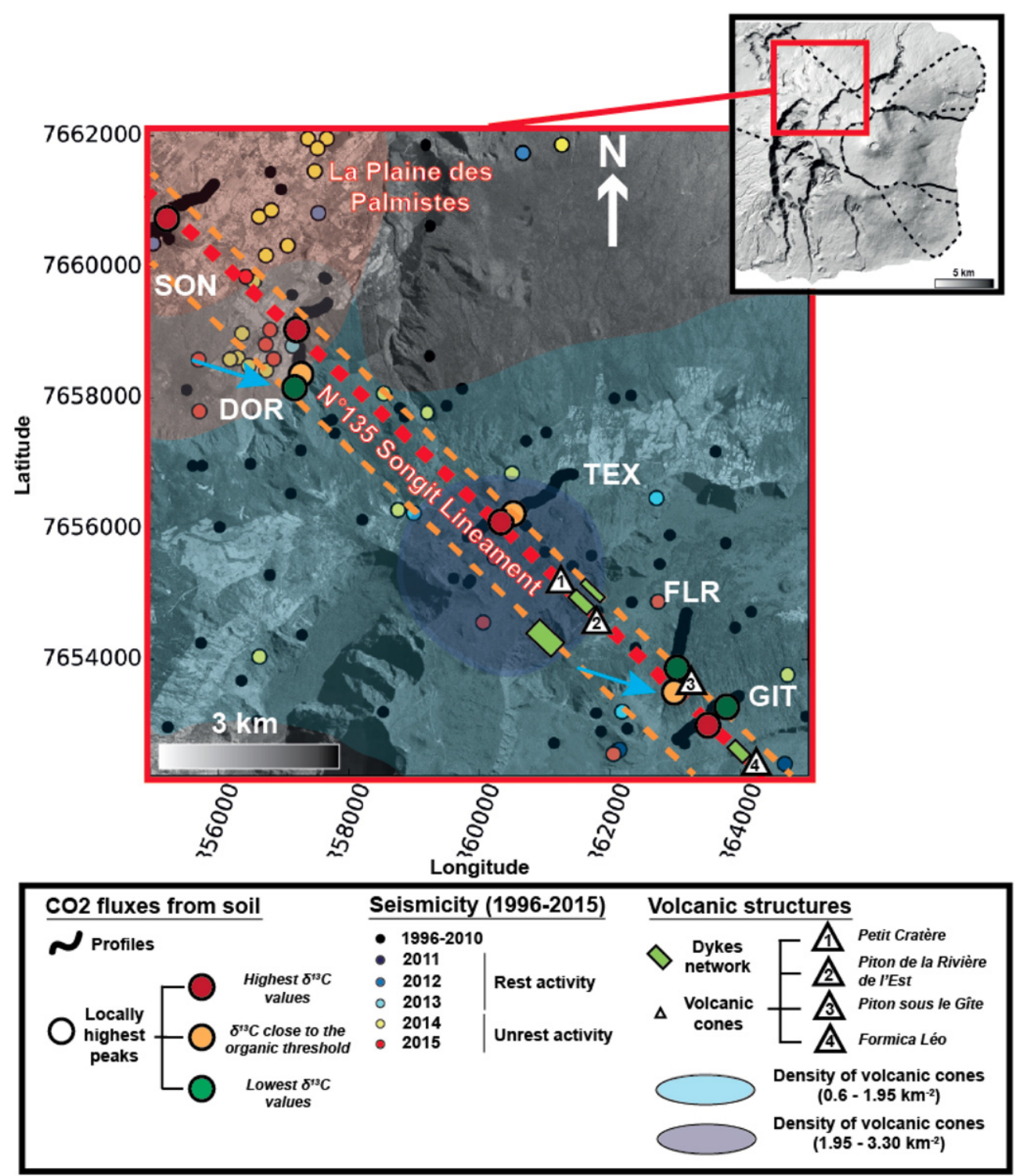

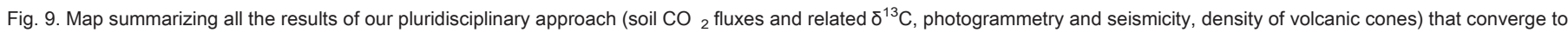
identify for the first time the Songit Lineament (between Piton des Songes (SON) and Piton sous le Gîte (GIT)). The structure has main N¹35 orientation (dashed red line) within the

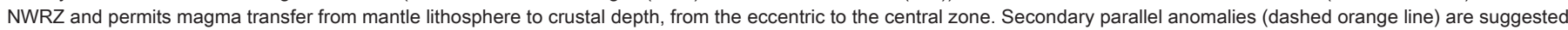

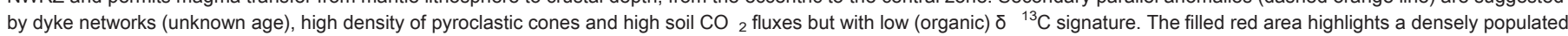

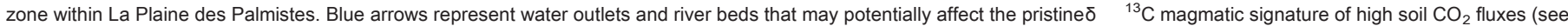
text for explanations)

for the first time the Songit Lineament) is parallel to an old series of dykes and of historical and pre-historic peripheral eruptive vents. The Songit Lineament has a well-defined $\mathrm{N} 135^{\circ}$ alignment, consistent with the orientation of paleo-spreading axes and probably resulting from the inheritance of the oceanic lithosphere. The location of the seismicity at mantle depths suggests that the structure is a main pathway for lateral magma migration and its reactivation heralds the reawakening of the central volcano. Our results stress the importance of multidisciplinary approaches to characterize active magmatic zones. Robust interpretation of soil $\mathrm{CO}_{2}$ flux datasets is strongly enhanced by isotopic analysis of $\mathrm{CQ}$ diffuse emissions. Low background emissions have a clear organic signature, while organic and magmatic signatures characterize zones of high diffuse emissions on the flanks of Piton de la Fournaise, set in a tropical environment. The results of our study open new perspectives for volcano monitoring at Piton de la Fournaise, in particular highlighting the necessity to improve our understanding and control of an active lineament located in a densely populated area. Continuous and combined geophysical and geochemical monitoring of the Songit Lineament is therefore strongly recommended.

Supplementary data to this article can be found online at http://dx. doi.org/10.1016/j.jvolgeores.2017.05.026.

\section{Acknowledgments}

We acknowledge many landowners on the flanks of Piton de la Fournaise for their help in letting us work into their private properties this field survey. Special thanks to G. P. A Torres (IGN-Spain) for supplying the software for the Sinclair (1974) procedure. P. Allard, A. Peltier and $\mathrm{V}$. Zanon are gratefully acknowledged for their constructive discussions. Appendix A (Table A1 and Fig. A1) is available as online Supporting Information. The Université de La Réunion and the ANR STRAP (ANR-14CE03-0004) have funded this work. This is IPGP contribution 3852. 

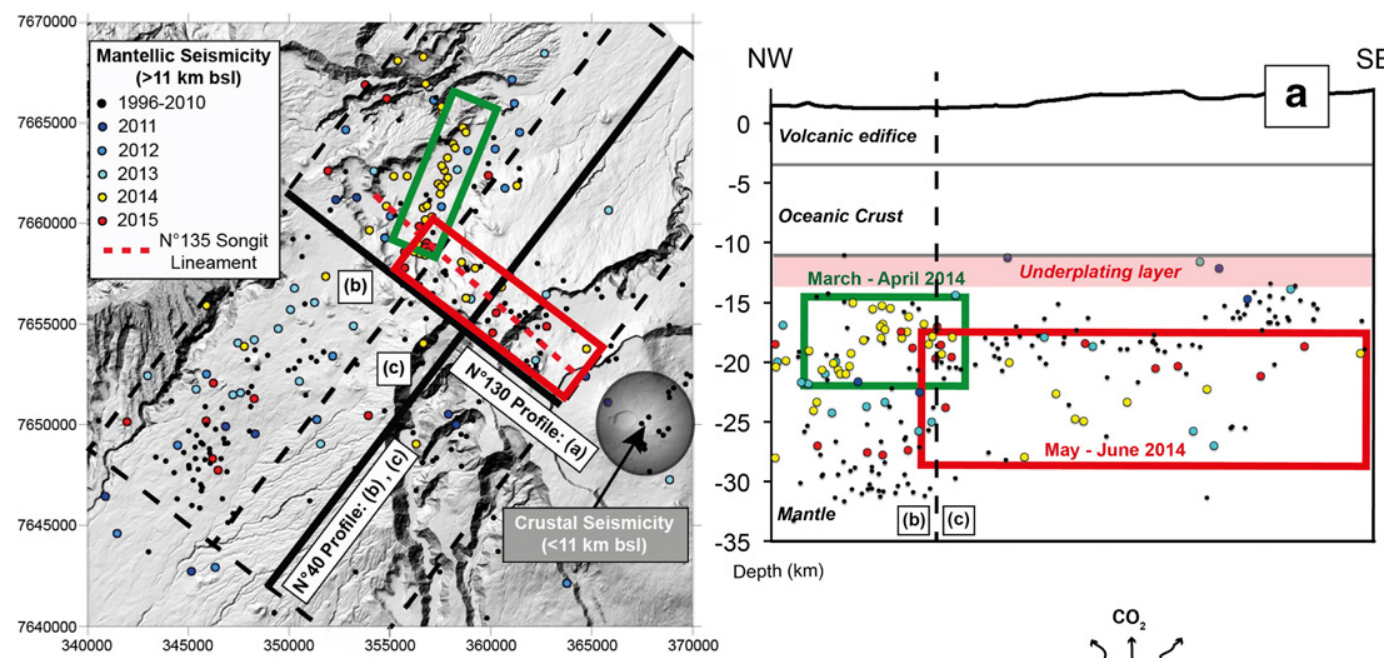

Depth $(\mathrm{km})$
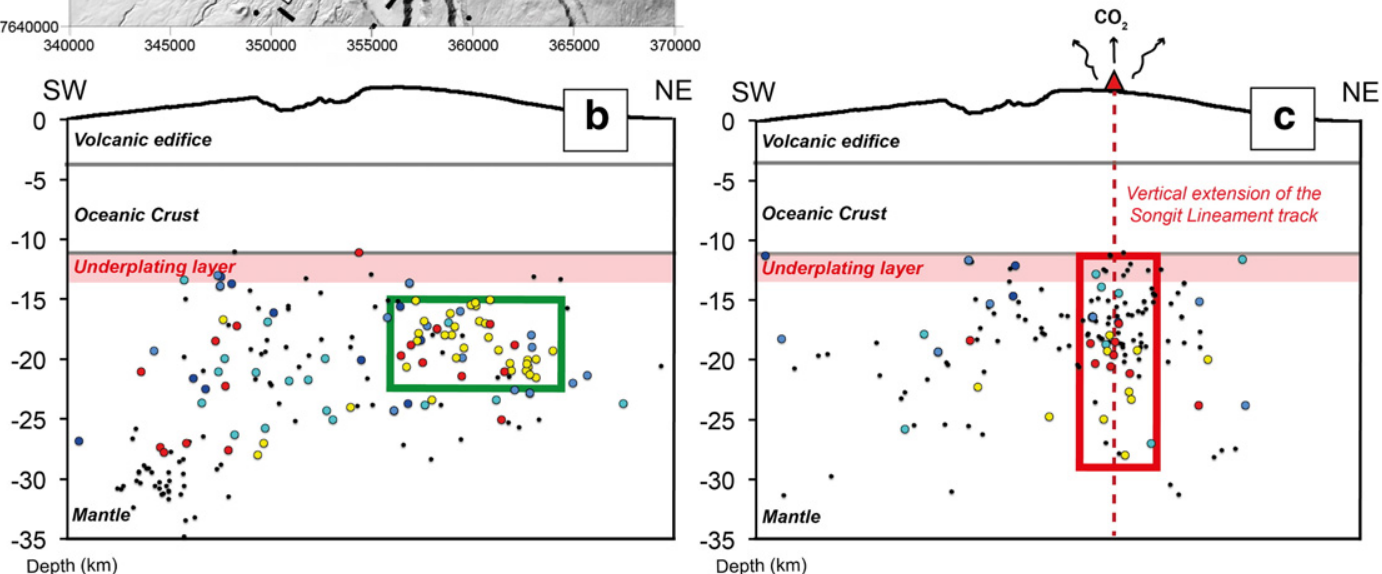

Fig. 10. Distribution of seismic events since 1996 below the western flank of the volcano at mantellic level. Depth of hypocenters projected (a) along the N130 ${ }^{\circ}$ orientation; (b) along a $\mathrm{N} 40^{\circ}$ orientation with only events detected below Le Tampon, La Plaine des Cafres and La Plaine des Palmistes and; (c) along a N40 ${ }^{\circ}$ orientation taking into account only the NWRZ. Fields used for the projection delimited by dashed black lines on the map.

References

Albarède, F., Luais, B., Fitton, G., Semet, M., Kaminski, E., Upton, B.G.J.Bachèlery, P., Cheminée, J.L., 1997. The geochemical regimes of Piton de la Fournaise volcano (Réunion) during the last 530000 years. J. Petrol. 38, 171-201.

Allard, P., Carbonnelle, J., Dajlevic, D., Lebronec,., Morel, P.,Robe, M.C., Maurenas, J.M., Faivrepierret, R., Martin, D., Sabroux, J.C.Zettwoog, P., 1991. Eruptive and diffuse emissions of CO2 from Mount Etna. Nature 351:387-391. http://dx.doi.org/10.1038/ $351387 a 0$.

Amundson, R., Stern, L., Baisden, T., Wang, Y., 1998. The isotopic composition of soil and soil-respired CO2. Geoderma 82 (1-3), 83-114.

Azzaro, R., Branca, S., Giammanco, S., Gurrieri, S., Rasà, R., Valenza, M., 1998. New evidence for the form and extent of the Pernicana Fault System (Mt. Etna) from structural and soil-gas surveying. J. Volcanol. Geotherm. Res. 84, 143-152.

Bachèlery, P., 1981. Le Piton de la Fournaise (lle de la Reunion) - Etude volcanologique, structurale et petrologique. Ph.D. thesis. University of Clermont-Ferrand (255 pp). Basile-Doelsch, I., Amundson, R., Stone, W.E.E., Borschneck, D., Bottero, J.Y., Moustie
Masin, F., Colin, F.2007. Mineral control of carbon pools in a volcanic soil horizon. Geoderma 137, 477-489.

Battaglia, J., Ferrazzini, V., Staudacher, T., Aki, K., Cheminée, J.L., 2005. Pre-eruptive migra- Came tion of earthquakes at the Piton de la Fournaise volcano (Réunion Island). Geophys J. Int. 161, 549-558.

Bennati, L., Finizola, A., Walker, J.A., Lopez, D.L., Higuera-Diaz, I.C., Schütze, C., Barahona, $\mathbb{E}$ Cartagena, R., Conde, V., Funes, R., 2011. Fluid circulation in a complex volcano-tectonic setting, inferred from self-potential and soil CO2 flux surveys: the Santa María-Cerro Quemado-Zunil volcanoes and Xela caldera (Northwestern Guatemala). J. Volcanol. Geotherm. Res.199 (3-4):216-229. http://dx.doi.org/10.1016/j.jvolgeores.2010.11. 008.

Bernard, A., Munschy, M., 2000. Were the Mascarene and Laxmi Basins (western Indian Ocean) formed at the same spreading centre? CR Acad Sci Paris Sci de la Terre et des Planètes. Earth Planet. Sci. 330, 777-783.

Boivin, P., Bachèlery, P., 2009. Petrology of 1977 to 1998 eruptions of Piton de la Fournaise La Réunion Island. J. Volcanol. Geotherm. Res. 184, 109-125.

Bonali, F.L., Corazzato, C., Tibaldi, A., 2011. Identifying rift zones on volcanoes: an example from La Réunion island, Indian Ocean. Bull. Volcanol. 73 (3), 347-366.
Bonforte, A., Federico, C.,Giammanco, S.,Guglielmino, F., Liuzzo, M., Neri, M., 2013. Soil gases and SAR measurements reveal hidden faults on the sliding flank of Mt. Etna (Italy). J. Volcanol. Geotherm. Res. 251, 27-40.

Boudoire, G., Brugier, Y.A., Di Muro, A., Wörner, G., Arienzo, I., Metrich, N., Zanon, V., Braukmüller, N., Kronz, A., Le Moigne, Y., Michon, L., Pichavant, M., 2017. Deep magma storage and migration at oceanic volcanic islands: insights from Piton de la Fournaise (La Réunion Island, Indian Ocean). J. Petrol. (in prep).

Boudoire, G., Di Muro, A., Liuzzo, M., Ferrazzini, V., Peltier, A., Gurrieri, S., Michon, L., Giudice, G., Kowalski, P., Boissier, P., 2017. New perspectives for the volcanic monitoring in tropical environment: continuous soil $\mathrm{CO}_{2}$ measurements at Piton de la Fournaise volcano (La Réunion Island). Geophys. Res. Lett. (submitted).

Brenguier, F., Shapiro, N., Campillo, M., Nercessian, A., Ferrazzini, V., 2007. 3-D surface wave tomography of the Piton de la Fournaise volcano using seismic noise correlations. Geophys. Res. Lett. 34, L02305

Bureau, H., Pineau, F., Metrich, N., Semet, M.P., Javoy, M., 1998. A melt and fluid inclusion study of the gas phase at Piton de la Fournaise volcano (Reunion Island). Chem. Geol. $147,115-130$

urton, M.R., Sawyer, G.M., Granieri, D., 2013. Deep carbon emissions from volcanoes: carbon in Earth. Rev. Mineral. Geochem. 75:323-354. http://dx.doi.org/10.2138/ rmg.2013.75.11.

Camarda, M., Gurrieri, S., Valenza,M., 2006a. CO2 flux measurements in volcanic areas using the dynamic concentration method: influence of soil permeability. J. Geophys. Res. 111, B05202. http://dx.doi.org/10.1029/2005JB003898.

amarda, M., Gurrieri, S., Valenza, M., 2006b. In situ permeability measurements based on a radial gas advection model: relationships between soil permeability and diffuse $\mathrm{CO} 2$ degassing in volcanic areas. Pure Appl. Geophys. 163 (4):897-914. http://dx.doi.org/ 10.1007/s00024-006-0045-y.

Cannata, A., Giudice, G., Gurrieri, S., Montalto, P., Alparone, S., Di Grazia, G., Favara, R., Gresta, S.,2010. Relationship be- tween soil CO2 flux and volcanic tremor at Mt. Etna: implications for magma dynamics. Environ. Earth Sci. 61:477-489. http://dx. doi.org/10.1007/s12665-009-0359-z

Cannata, A., Spedalieri, G., Behncke, B., Cannavò, F., Di Grazia, G., Gambino, S., Gresta, S. Gurrieri, S., Liuzzo, M., Palano, M., 2015. Pressurization and depressurization phases inside the plumbing system of Mount Etna volcano: evidence from a multiparametric approach. J.Geophys. Res. Solid Earth 120:5965-5982. http://dx.doi.org/10.1002/ 2015JB012227. 
Cerling, T.E., Solomon, D.K., Quade, J.A.Y., Bowman, J.R., 1991. On the isotopic compositionGranieri, D., Avino, R., Chiodini, G., 2010. Carbon dioxide diffuse emission from the soil: of carbon in soil carbon dioxide. Geochim. Cosmochim. Acta 55:3403-3405. http://dx. doi.org/10.1016/0016-7037(91)90498-T.

Chevallier, L., 1979. Structures et évolution du volcan Piton des Neiges, île de la Réunion: Leurs relations avec les structures du Bassin des Mascareignes, Océan Indien occidental. Ph.D. Thesis. Université de Grenoble.

Chevallier, L., Bachèlery, P., 1981. Evolution structurale du volcan actif du Piton de la Fournaise, Ile de la Réunion - Océan Indien occidental. Bull. Volcanol. 44, 723-741.

Chiodini, G., Cioni, R., Guidi, M., Raco, B., Marini, L., 1998. Soil CO2 flux measurements in volcanic and geothermal areas. Appl. Geochem. 13:543-552. http://dx.doi.org/10. 1016/S0883-2927(97)00076-0.

Chiodini, G., Frondini, F., Cardellini, C., Granieri, D., Marini, L., Ventura, G., 2001. CO2 degassing and energy release at Solfatara volcano, Campi Flegrei, Italy. J.Geophys. Res. 106. http://dx.doi.org/10.1029/2001JB000246.

Chiodini, G., Caliro, S., Cardellini, C., Avino, R., Granieri, D., Schmidt, A , 2008 Carbon isotopic composition of soil CO2 efflux, a powerful method to discriminate different sources feed- J ing soil CQdegassing in volcanic-hydrothermal areas. Earth Planet. Sci. Lett. 274, 372-379.

Coppola, D., Di Muro, A., Peltier, A., Villeneuve, N., Ferrazzini, V., Fatally, M., Bachèlery, P. Gurioli, L., Harris, A.J.L., Moune, S., Vlastélic, I., Galle, B., Arellano, S., Aiuppa, A., 2017. Shallow system rejuvenation and magma discharge trends at Piton de la Fournaise volcano (La Réunion Island). Earth Planet. Sci. Lett. 463, $13-24$.

Deegan, F.M., Troll, V.R., Freda, C. Misiti, V., Chadwick, J.P., McLeod, C.L., Davidson, J.P., Magma-carbonate interaction processes and associated $\mathrm{CO} 2$ release at Merapi volcano, Indonesia: insights from experimental petrology. J. Petrol. 51, 1027-1051.

Deniel, C., Kieffer, G., Lecoindre, J., 1992. New 230Th-238U and 14C age determinations from Piton des Neiges volcano, Reunion - a revised chronology for the differentiated series. J. Volcanol. Geotherm. Res. 51, 253-267.

Di Muro, A., Métrich, N., Allard, P., Aiuppa, A., Burton, M., Galle, B., Staudacher, T., 2016. Magma Degassing at Piton de la Fournaise Volcano. In: Bachèlery, P., Lénat, J.F.Di Muro, A., Michon, L. (Eds.), Active Volcanoes of the Southwest Indian Ocean: Piton de la Fournaise and Karthala. Active Volcanoes of the World. Springer, Berlin.

Diliberto, I.S., Gurrieri, S., Valenza, M., 2002. Relationships between diffuse CO2 emissions and volcanic activity on the island of Vulcano (Aeolian Island, Italy) during the period 1984-1994. Bull. Volcanol. 64, 219-228. ten years of observations at Vesuvio and Campi Flegrei (Pozzuoli), and linkages with volcanic activity. Bull. Volcanol. 72 (1), 102-118.

Gurrieri, S., Valenza, M., 1988.Gas transport in natural porous mediums: a method for measuring $\mathrm{CO} 2$ flows from the ground in volcanic and geothermal areas. Rend. Soc. Ital. Mineral. Petrol. 43, 1151-1158.

Gurrieri, S., Liuzzo, M., Giudice, G., 2008. Continuous monitoring of soil CO2 flux on Mt. Etna: The 2004-2005 eruption and the role of regional tectonics and volcano tectonics. J. Geophys. Res. 113. http://dx.doi.org/10.1029/2007JB005003.

Hernández, P.A.,Pérez, N.M., Fredriksson, T., Egbert, J.,llyinskaya, E., Thárhallsson, A. Ívarsson, G., Gíslason, G., Gunnarsson, I., Jansson, B., 2012. Diffuse volcanic degassing and thermal energy release from Hengill volcanic system, Iceland. Bull. Volcanol. 74, 2435-2448.

Irwin, W.P., Barnes, I., 1980. Tectonic relations of carbon dioxide discharges and earthquakes. J. Geophys. Res. 85. http://dx.doi.org/10.1029/JB085iB06p03115

in, J.L., Folio, J.L., Robineau, B., 2005. Aquifers and groundwater within active shield volcanoes. Evolution of conceptual models in the Piton de la Fournaise volcano. J. Volcanol. Geotherm. Res. 147, 187-201.

de Junet, A., Basile-Doelsch, I., Borschneck, D., Masion, A., Legros, S., Marol, C., Balesdent, J., Templier, J., Derenne, S., 2013. Characterisation of organic matter from organo-mineral complexes in an Andosol from Reunion Island. J. Anal. Appl. Pyrolysis 99, 92-100.

onprobst, J., Boivin, P., Lénat, J.F., Bachèlery, P., Bonneville, A., Dupont, P., Lecointre, J., Seidel, J.L., Thomas, P., Vincent, P.M., 1984. Le Piton de la Fournaise, île de la Réunion. Colloque Prévision et Surveillance des Eruptions Volcaniques (C.N.R.S.-I.N.A.G.) Clermont-Ferrand, pp. 75-82.

Lénat, J.F., Gibert-Malengreau, B., Galdeano, A., 2001. A new model for the evolution of the volcanic island of Reunion (Indian Ocean). J. Geophys. Res. B 106 (5), 8645-8663.

Lénat, J.F., Bachèlery, P., Merle, O., 2012. Anatomy of Piton de la Fournaise volcano (La Réunion, Indian Ocean). Bull. Volcanol. 74, 1945-1961.

Lengliné, O., Duputel, Z., Ferrazzini, V., 2016. Uncovering the hidden signature of a magmatic recharge at Piton de la Fournaise volcano using small earthquakes. Geophys. Res. Lett. 43. http://dx.doi.org/10.1002/2016GL068383.

Liuzzo, M., Di Muro, A., Giudice, G., Michon, L., Ferrazzini, V., Gurrieri, S., 2015. New evidence of $\mathrm{CO} 2$ soil degassing anomalies on Piton de la Fournaise volcano and the

Dionis, S.M., Melián, G., Rodríguez, F., Hernández, P.A., Padrón, E., Pérez, N.M., Barrancos, J., link with volcano tectonic structures. Geochem. Geophys. Geosyst. 16. http://dx.doi. Padilla, G., Sumino, H., Fernandes, P., Bandomo, Z., Silva, S., Pereira, J., Semedo, H., 2015. org/10.1002/2015GC006032.

Diffuse volcanic gas emission and thermal energy release from the summit crater of Pico do Fogo, Cape Verde. Bull. Volcanol. 77 (2)

Elio, J., Ortega, M.F., NisiB., Mazadiego, L.F., Vaselli, OCaballero, J., Chacon, E., 2016. A multi-statistical approach for estimating the total output of $\mathrm{CO} 2$ from diffusive soil degassing by the accumulation chamber method. Int. J. Greenh. Gas Con. 47, 351-363.

Feder, F., 2013. Soil map update: procedure and problems encountered for the island of Réunion. Catena 110, 215-224.

Finizola, A., Sortino, F., Lénat, J.F., Aubert, M., Ripepe, M., Valenza, M., 2003. The summit hydrothermal system of Stromboli: new insights from self-potential, temperature, $\mathrm{CO} 2$ and fumarolic fluids measurements, with structural and monitoring implications. Bull. Volcanol. 65:486-504. http://dx.doi.org/10.1007/s00445-003-0276-2

Finizola, A., Lénat, J.F., Macedo, O., Ramos, D., Thouret, J.C., Sortino, F., 2004. Fluid circ and structural discontinuities inside Misti volcano (Peru) inferred from self-potentia measurements. J.Volcanol. Geotherm. Res.135 (4):343-360. http://dx.doi.org/10. 1016/j.jvolgeores.2004.03.009

Folio, J.-L., 2001. Distribution de la perméabilité dans le massif du Piton de la Fournaise: apport à la connaissance du fonctionnement hydrogéologique dun volcan-bouclier. Ph.D. thesis. University of La Réunion (148 p).

Fontaine, F.R.,Barruol, G., Tkalčić,H., Wölbern, I., Rümpker, G., Bodin, T.,Haugmard, M., 2015. Crustal and uppermost mantle structure variation beneath La Réunion hotspot track. Geophys. J. Int. 203, 107-126.

Gallart, J., Driad, L., Charvis, P., Sapin, M., Hirn, A., Diaz, J., de Voogd, B., Sachpazi, M., Perturbation to the lithosphere along the hotspot track of La Réunion from an offshoreonshore seismic transect. J. Geophys. Res. 104, 2895-2908.

Giammanco, S., Bonfanti, P., 2009. Cluster analysis of soil CO2 data from Mt. Etna (Italy) reveals volcanic influences on temporal and spatial patterns of degassing. Bull. Volcanol. 71, 201-218

Giammanco, S., Gurrieri, S., Valenza, M., 1995 Soil CO2 degassing on Mt. Etna (Sicily) during the period 1989-1993: discrimination between climatic and volcanic influences. Bull. Volcanol. 57, 52-60

Giammanco, S., Gurrieri, S., Valenza, M., 1997. Soil_e@egassing along tectonic structures of Mount Etna (Sicily): the Pernicana Fault. Appl. Geochem. 12, 429-436.

Giammanco, S., Ottaviani, M., Valenza, M., Veschetti, E., Principio, E., Giammanco, G. Pignato, S., 1998. Major and trace elements geochemistry in the ground waters of a volcanic area: Mount Etna (Sicily). Water Res. 32, 19-30.

Giammanco, S., Gurrieri, S.,Valenza, M., 2006. Fault-controlled soil CO2 degassing and shallow magma bodies: summit and lower east rift of Kilauea volcano (Hawaii), 1997. Pure Appl. Geophys. 163 (4), 853-867.

Giammanco, S., Bellotti, F., Groppelli, G., Pinton, A., 2010. Statistical analysis reveals spatia and temporal anomalies of soil CO2 efflux on Mount Etna volcano (Italy). J. Volcanol. Geotherm. Res. 194, 1-14.

Gillot, P.Y., Nativel, P., 1989. Eruptive history of the Piton de la Fournaise volcano, Reunion Island, Indian Ocean. J. Volcanol. Geotherm. Res. 36, 53-65.

González, P.J.,Samsonov, S.V.,Pepe, S., Tiampo, K.F., Tizzani, P., Casu,F., Fernández, J., Camacho, A.G., Sansosti, E., 2013. Magma storage and migration associated with the 2011-2012 El Hierro eruption: implications for crustal magmatic systems at oceanic island volcanoes. J. Geophys. Res. Solid Earth 118 (8), 4361-4377.

Granieri, D., Chiodini, G., Marzocchi, W., Avino, R., 2003. Continuous monitoring of CO2 soil diffuse degassing at Phlegraean Fields (Italy): influence of environmental and volcanic parameters. Earth Planet. Sci. Lett. 212, 167-179.

ópez, C., Blanco, M.J., Abella, R., Brenes, B., Cabrera-Rodríguez, V.M., Casas, B., Domínguez-Cerdeña, I., Felpeto, A.,Fernández de Villalta, M., del Fresno, C.,GarcíaArias, M.J., García-Canada, L., Gomis-Moreno, A., González-Alonso, E., GuzmánPérez, J., Iribarren, I., López-Díaz, R., Luengo-Oroz, N., Meletlidis, S., Moreno, M., Moure, D., Pereda de Pablo, J., Rodero, C., Romero, E., Sainz-Maza, S., SentreDomingo, M.A., Torres, P.A., Trigo, P., Villasante-Marcos, V., 2012. Monitoring the volcanic unrest of El Hierro (Canary Islands) before the onset of the 2011-2012 submarine eruption. Geophys. Res. Lett. 39.

Marty, B., Meynier, V., Nicolini, E., Griesshaber, E., Toutain, J.P., 1993. Geochemistry of gas emanations: a case study of the Réunion hot spot, Indian ocean. Appl. Geochem. 8 , $141-152$.

assin, F., 2009. Transferts et Stockages Magmatiques au Piton de la Fournaise. Ph.D. thesis. Université de la Réunion (176pp).

McDougall, I., 1971. The geochronology and evolution of the young volcanic island of Réunion (Indian Ocean). Geochim. Cosmochim. Acta 35, 261-288.

Michel, S., Zlotnicki, J., 1998. Self-potential and magnetic surveying of La Fournaise volcano (Reunion Island): correlation with faulting, fluid circulation, and eruption. J. Geophys. Res. 103.

Michon, L., Saint-Ange, F., Bachelery, P., Villeneuve, N., Staudacher, T., 2007. Role of the structural inheritance of the oceanic lithosphere in the magmato-tectonic evolution of Piton de la Fournaise volcano (La Réunion Island). J. Geophys. Res. Solid Earth 112, 1-21. lichon, L., Di Muro, A., Villeneuve, N., Saint-Marc, C., Fadda, P., Manta, F., 2013. Explosive activity of the summit cone of Piton de la Fournaise volcano (La Réunion island): a historical and geological review. J. Volcanol. Geotherm. Res. 263, 117-133.

Michon, L., Ferrazzini, V., Di Muro, A., Villeneuve, N., Famin, V., 2015. Rift zones and magma plumbing system of Piton de la Fournaise volcano: how do they differ from Hawaii and Etna. J. Volcanol. Geotherm. Res. 303, 112-129.

Michon, L., Lénat, J.F., Bachèlery, P., Di Muro, A., 2016. Geology and morphostructural evolution of Piton de la Fournaise. In: Bachèlery, P., Lénat, J.F.Di Muro, A., Michon, L. (Eds.), Active Volcanoes of the Southwest Indian Ocean: Piton de la Fournaise and Karthala. Active Volcanoes of the World. Springer, Berlin.

Moldrup, P., Yoshikawa, S., Olesen, T., Komatsu, T., Rolston, D.E., 2003. Gas diffusivity in undisturbed volcanic ash soils: test of soil water-characteristic based prediction models. Soil Sci. Soc. Am. J. 67, 41-51.

Mook, W.G.,Bommerson, J.C.Staverman, W.H., 1974. Carbon isotope fractionation between dissolved bicarbonate and gaseous carbon dioxide. Earth Planet. Sci. Lett. 22 169-176.

Morandi, A., Di, Muro A., Principe, C., Michon, L., Leroi, G., Norelli, F., Bachèlery, P., 2016. Prehistoric explosive activity at Piton de la Fournaise volcano. In: Bachèlery, P., Lénat, J.F. Di Muro, A., Michon, L. (Eds.), Active Volcanoes of the Southwest Indian Ocean: Piton de la Fournaise and Karthala. Active Volcanoes of the World. Springer, Berlin.

Moretti, R., Papale, P., 2004. On the oxidation state and volatile behavior in multicomponent gas-melt equilibria. Chem. Geol. 213, 265-280.

Ort, M., Di Muro, A., Michon, L., Bachèlery, P., 2016. Explosive eruptions from the interaction of magmatic and hydrothermal systems during $\mathrm{fl}$ ank extension: the Bellecombe ashes of Piton de la Fournaise (La Réunion Island). Bull. Volcanol. (accepted).

Papale, P., 1999. Modeling of the solubility of a two-component $\mathrm{H} 2 \mathrm{O}+\mathrm{CO} 2$ fluid in silicate liquids. Am. Mineral. 84, 477-492.

Papale, P., Moretti, R., Barbato, D., 2006. The compositional dependence of the saturation surface of $\mathrm{H} 2 \mathrm{O}+\mathrm{CO} 2$ fluids in silicate melts. Chem. Geol. 229, 78-95. 
Patanè, D., Aiuppa, A., Aloisi, M., Behncke, B., Cannata, A., Coltelli, M., Di Grazia, G., Gambino, S., Gurrieri, S., Mattia, M., Salerno, G., 2013. Insights into magma and fluid transfer at Mount Etna by a multiparametric approach: a model of the events leading to the 2011 eruptive cycle. J. Geophys. Res. Solid Earth 118:3519-3539. http://dx.doi. org/10.1002/jgrb.50248.

Peltier, A., Bachèlery, P., Staudacher, T., 2009. Magma transport and storage at Piton de la Fournaise (La Réunion) between 1972 and 2007: a review of geophysical and geochemical data. J. Volcanol. Geotherm. Res. 184, 93-108.

Peltier, A., Beauducel, F., Villeneuve, N., Ferrazzini, V., Di Muro, A., Aiuppa, A., Derrien, A., Jourde, K., Taisne, B., 2016. Deep fluid transfer evidenced by surface deformation during the 2014-2015 unrest at Piton de la Fournaise volcano. J. Volcanol. Geotherm. Res. $321,140-148$

Pérez, N.M., Padilla, G.D., Padrón, E., Hernández, P.A., Melián, G.V., Barrancos, J., Dionis, S., Nolasco, D., Rodríguez, F., Calvo, D., Hernández, I., 2012. Precursory diffuse CO2 and H2S emission signatures of the 2011-2012 El Hierro submarine eruption Canary Islands. Geophys. Res. Lett. 39. http://dx.doi.org/10.1029/2012GL052410.

Revil, A., Finizola, A., Piscitelli, S., Rizzo, E., Ricci, T., CrespAl, Angeletti, B., Balasco, M., Barde Cabusson, S., Bennati, L., Bolève, A., Byrdina, S., Carzaniga, N., Di Gangi, F., Morin, J.,Perrone, A., Rossi, M., Roulleau, E., Suski, B., 2008. Inner structure of La Fossa di Vulcano (Vulcano Island, southern Tyrrhenian Sea, Italy) revealed by high resolution electric resistivity tomography coupled with self-potential, temperature, and CO2 diffuse degassing measurements. J. Geophys. Res. 113. http://dx.doi.org/10 1029/2007JB005394.

Revil, A., Finizola, A., Ricci, T., Delcher, E., Peltier, A., Barde-Cabusson, S., Avard, G., Bailly, Byrdina, S., Colonge, J., Di Gangi, F., Douillet, G., Lupi, M., Letort, J., Tsang Hin Sun, E., 2011. Hydrogeology of Stromboli volcano, Aeolian Islands (Italy) from the interpretation of resistivity tomograms, self-potential, soil temperature, and $\mathrm{CO} 2$ concentration measurements. Geophys. J.Int. 186:1078-1094. http://dx.doi.org/10.1111/j.1365246X.2011.05112.x.
Roult, G., Peltier, A., TaisneB., Staudacher,T., Ferrazzini, V., Di Muro, A., Team, O.V.P.F. 2012. A new comprehensive classification of the Piton de la Fournaise activity spanning the 1985-2010 period. Search and analysis of short-term precursors from a broad-band seismological station. J. Volcanol. Geotherm. Res. 241-242, 78-104.

Seidel, J.L.,Bonneville, A., Lenat, J.F.,1988. Radon measurements related to Piton de la Fournaise (Réunion) from 1983 to 1987. C.R. Acad. Sci. Paris 306, 89-92.

Sinclair, A.J.,1974. Selection of threshold values in geochemical data using probability graphs. J. Geochem. Explor. 3, 129-149.

Toutain, J.P.,Baubron, J.C.,1999. Gas geochemistry and seismotectonics: a review. Tectonophysics 304, 1-24

Toutain, J.P., Baubron, J.C., François, L., 2002. Runoff control of soil degassing at an active volcano. The case of Piton de la Fournaise, Réunion Island. Earth Planet. Sci. Lett. 19, 83-94.

Troll, V.R., Hilton, D.R., Jolis, E.M., Chadwick, J.P., Blythe, L.S., Deegan, F.M., Schwarzkopf, L.M., Zimmer, M., 2012. Crustal CO2 liberation during the 2006 eruption and earthquake events at Merapi volcano, Indonesia. Geophys. Res. Lett. 39. http://dx.doi.org/ 10.1029/20 12GL051307.

Trull, T., Nadeau, S., Pineau, F., Polvé, M., Javoy, M., 1993. C-He systematics in hotspot xenoliths: implications for mantle carbon contents and carbon recycling. Earth Planet. Sci. Lett. 118, 43-64.

Upton, B.G.J., Semet, M., Joron, J.L., 2000. Cumulate clasts in the Bellecombe Ash Member, Piton de la Fournaise, Réunion Island, and their bearing on cumulative processes in the petrogenesis of the Réunion lavas. J. Volcanol. Geotherm. Res. 104, 297-318.

V.jlleneuve, N., Bachèlery, P., 2006. Revue de la typologie des éruptions au Piton de la Fournaise, processus et risques volcaniques associés. Cybergeo 2006, 1-25.

Wright, T.L., Klein, F.W., 2006. Deep magma transport at Kilauea volcano, Hawaii. Lithos 87:50-79. http://dx.doi.org/10.1016/j.lithos.2005.05.004. 